\title{
U-Th stratigraphy of a cold seep carbonate crust
}

\author{
G. Bayon ${ }^{a}{ }^{*}$, G.M. Henderson ${ }^{b}$ and M. Bohn ${ }^{c}$ \\ a Département Géosciences Marines, Ifremer, 29280 Plouzané, France \\ ${ }^{b}$ Department of Earth Sciences, Oxford University, Parks Road, OX1 3PR Oxford, UK \\ ${ }^{c}$ Microsonde Ouest, CNRS-UMR 6538, Ifremer, 29280 Plouzané, France \\ *: Corresponding author: G. Bayon, Tel.: +33 2982246 30; fax: +33 29822 45 70, email address : \\ Germain.Bayon@ifremer.fr
}

\begin{abstract}
:
On continental margins, oxidation of methane-rich fluids from the sediment often leads to formation of authigenic carbonate pavements on the seafloor. The biogeochemical processes involved during this carbonate precipitation are increasingly understood, but little is known about the duration or mode of carbonate crust formation. Here, we report uranium and thorium concentrations and isotope compositions for a set of 14 samples drilled across an authigenic carbonate pavement, which provide the first stratigraphy for a cold-seep carbonate crust. The 5.5-cm thick crust (NL7-CC2) was collected by submersible on the Nile deep-sea fan in an area of active fluid venting. U-Th analyses must be corrected for initial Th and measurement of co-existing sediments indicates the presence of both scavenged and detrital initial ${ }^{230} \mathrm{Th}$, which must be considered during this correction. The calculated ${ }^{230} \mathrm{Th} / \mathrm{U}$ age-depth profile for NL7-CC2 provides evidence for continuous downward carbonate precipitation at the studied location over the last $\sim 5000$ years. Three distinct phases can be distinguished from top to bottom with average growth rates of $\sim 0.4,5$ and $0.8 \mathrm{~cm} / \mathrm{kyr}$, respectively, corresponding to carbonate precipitation rates ranging from $\sim 7$ to $92 \mu \mathrm{mol} \mathrm{m} \mathrm{m}^{2} \mathrm{~h}^{-1}$ (rates consistent with previous estimates). High-resolution $\delta^{13} \mathrm{C}$ profiles [Gontharet, S., Pierre, C., Blanc-Valleron, M.M., Rouchy, J.M., Fouquet, Y., Bayon, G., Foucher, J.P., Woodside, J., Mascle, J., The Nautinil Scientific Party, 2007. Nature and origin of diagenetic carbonate crusts and concretions from mud volcanoes and pockmarks of the Nile deep-sea fan (eastern Mediterranean Sea). Deep Sea Res. II 54, 1292-1311] and major elements across NL7-CC2 show that the variations in carbonate precipitation rates were also accompanied by changes in carbonate mineralogy and fluid composition. We suggest that these changes primarily reflect modification of the diagenetic environment, i.e. a progressive depletion of dissolved sulphate through anaerobic oxidation of methane, caused by the initial carbonate crust formation and the resulting reduction in bioirrigation. Overall, U-Th dating of cold seep carbonates offers a promising tool to bring new insights into biogeochemical processes at cold seeps and to assess the timing and duration of fluid venting on continental margins.
\end{abstract}

Keywords: U-series; Authigenic carbonates; Cold seeps; Nile fan 


\section{Introduction}

Cold seep carbonates are a promising archive of past fluid flow and gas hydrate dissociation on continental margins. They typically form in sub-surface sediments at cold seeps, resulting from the microbial oxidation of methane-rich fluids (e.g. Ritger et al., 1987; Hovland et al., 1987; Paull et al., 1992; Bohrmann et al., 1998; Aloisi et al., 2000, 2002; Greinert et al., 2001; Michaelis et al., 2002; Mazzini et al., 2004; Reitner et al., 2005; Stadnitskaia et al., 2005; Gontharet et al., 2007). In fluid venting areas, anaerobic oxidation of methane (AOM) leads to enhanced alkalinity and dissolved sulphide contents in pore waters, which favours carbonate precipitation and the development of chemosynthetic communities on the seafloor.

In many settings, carbonate precipitation forms a hard crust at the sediment surface. Numerical modelling indicate that such carbonate crusts may form within a time period of several centuries (Luff and Wallmann, 2003; Luff et al., 2004, 2005), but these estimates of growth rate and duration have not been confirmed with chronological observations and little is known about the effect of crust growth on fluid venting. To address these questions requires establishing an accurate chronology for crust formation. This cannot be achieved using radiocarbon techniques because coldseep carbonates derive part of their carbon from old sources (i.e. methane). A few previous studies have demonstrated that U-series could be used successfully to date cold seep carbonates from modern fluid venting systems (Lalou et al., 1992; Teichert et al., 2003; Watanabe et al., 2008), but there has been no detailed investigation of crust formation at a single site to allow reconstruction of paleo-methane seepage history at a high-resolution temporal scale.

The major difficulty in dating cold-seep carbonates is that they often incorporate a significant fraction of detrital sediment (e.g. clays), which represents a major source of initial ${ }^{230} \mathrm{Th}$ (i.e. not produced by in situ decay). Such detrital ${ }^{230} \mathrm{Th}$ is accompanied by a much larger amount of ${ }^{232} \mathrm{Th}$, because the ${ }^{230} \mathrm{Th} /{ }^{232} \mathrm{Th}$ ratio in most geological materials is $\sim 5 \times 10^{-6}$. A typical correction procedure for dating dirty carbonates is the measurement of the isotopic composition of the contaminating phase (i.e. sediment)

60 using isochron techniques (e.g. Luo and Ku, 1991; Bischoff and Fitzpatrick, 1991;

61 Edwards et al., 2003). Isochron methods consider each sample to be composed of a mixture of two components and are used to separate ${ }^{230} \mathrm{Th}$ present initially (i.e. detrital ${ }^{230} \mathrm{Th}$ ) from that ingrown from $\mathrm{U}$ in the carbonate. Concern may arise however when more than one component of initial thorium exists in the carbonate samples, each with 
65 its own ${ }^{230} \mathrm{Th} /{ }^{232} \mathrm{Th}$ ratios (Lin et al., 1996). This is the case when carbonates contain a

66 source of ${ }^{230} \mathrm{Th}$ scavenged from seawater, in addition to detrital ${ }^{230} \mathrm{Th}$ and radiogenic

$67{ }^{230}$ Th (Lin et al., 1996; Henderson et al., 2001). Hence, the origin of initial ${ }^{230} \mathrm{Th}$ in

68 any cold seep carbonate samples must be distinguished in order to obtain reliable age

69 information with isochron methods.

71 In this study, we present the first high-resolution stratigraphy for a cold-seep

72 carbonate crust. U-Th carbonate age data were acquired on a series of samples drilled 73 across a carbonate pavement from the Nile deep-sea fan. The U-Th age-depth profile

74 is used together with $\delta^{13} \mathrm{C}$ (Gontharet et al., 2007) and major element data to determine

75 carbonate precipitation rates and to provide new insights on the factors affecting crust

76 formation at cold seeps.

\section{Description of NL7-CC2 crust}

The carbonate crust analysed in this study was recovered offshore Egypt by submersible during the Nautinil expedition (RV Atalante, 2003), on the Nile deep-sea

83 fan (Eastern Mediterranean basin; Fig. 1). Crust NL7-CC2 was collected from a large

$84\left(>1 \mathrm{~km}^{2}\right)$ carbonate-paved area associated with chemosynthetic vent communities at $851650 \mathrm{~m}$ water depth (Fig. 2A; Bayon et al., In press). It is a $~ 5.5 \mathrm{~cm}$-thick, highly 86 porous, carbonate-cemented mudstone, covered by a fine layer of Fe-oxyhydroxides 87 (Fig. 2B). The bulk crust density is $1.6 \mathrm{~g} \mathrm{~cm}^{3}$. Gontharet et al. (2007) showed that 88 crust NL7-CC2 is dominated by aragonite, but exhibits mineralogical variability, 89 characterized by a gradual enrichment in high-Mg carbonate phases from top to bottom 90 (Fig. 2B). Examination of NL7-CC2 under optical and scanning electron microscopes 91 shows that this change from aragonite to calcite is not due to aragonite recrystallisation 92 (Gontharet et al., 2007). The $\sim 1-\mathrm{cm}$ top part of the crust is composed of various 93 fragments of chemosynthetic bivalve shells (Vesycomyidae and Thyasiridae; Bayon et 94 al., In press), cemented by aragonite (Fig. 2B). Upon recovery, numerous living 95 vestimentiferan tubeworms were observed anchored at the base of the crust, which 96 indicate that active fluid venting occurs at that site (Fig. 2A). Fibrous aragonite is 97 present typically in open pore spaces, either in cracks or inside the cavities of biogenic 98 components (e.g. foraminifers, bivalve shells). 


\section{Analytical techniques}

\subsection{Electron microprobe analysis and XRF}

Polished sections of crust NL7-CC2 were examined by scanning electron microscopy (JEOL JSM-840A, University of Oxford) to select sampling areas suitable

106 for U-Th measurements based on the texture of carbonate growth. To assess the bulk 107 major element composition, five $\sim 1-\mathrm{cm}$-thick slices sampled across a section of NL7108 CC2 crust were analysed by wavelength-dispersive X-ray fluorescence (WD-XRF) 109 analysis of fusion beads. These analyses were performed on the same powders 110 analysed for mineralogy and $\delta^{13} \mathrm{C}$ by Gontharet et al. (2007). In addition, high111 resolution abundance profiles of $\mathrm{Ca}, \mathrm{Mg}, \mathrm{Sr}, \mathrm{Si}, \mathrm{Al}, \mathrm{Ti}, \mathrm{Fe}, \mathrm{K}, \mathrm{P}, \mathrm{Mn}, \mathrm{C}$ and $\mathrm{O}$ were 112 measured by electron microprobe (Cameca SX50, Microsonde Ouest, IFREMER) on 113 one thin section of NL7-CC2 crust cross cut perpendicular to its growth banding. 114 Analyses were made using an accelerating voltage of $15 \mathrm{kV}$ and a beam current of 10 $115 \mathrm{nA}$. Spot analyses of the crusts were made at a resolution of $0.1 \mathrm{~mm}$ with a $20 \mu \mathrm{m}$ 116 beam diameter. The relative error for each element is approximately $1 \%(1 \sigma)$ for 117 concentrations in the range $10-30 \mathrm{wt} \%$, but increases to about $10 \%(1 \sigma)$ for 118 concentrations between 0.1 and $0.5 \mathrm{wt} \%$. The porous nature of the crust, and the fact 119 that both $\mathrm{C}$ and $\mathrm{O}$ were measured during analysis, resulted in oxide totals mostly 120 higher than $105 \%$. Analyses with totals more than $115 \%$ were rejected and other 121 analyses were normalized to a $100 \%$ total. For both XRF and electron microprobe data, 122 detrital contents along the crust were estimated simply by summing contents of $\mathrm{K}_{2} \mathrm{O}$, $123 \mathrm{Fe}_{2} \mathrm{O}_{3}, \mathrm{SiO}_{2}, \mathrm{TiO}_{2}$ and $\mathrm{Al}_{2} \mathrm{O}_{3}$.

\subsection{Sampling, chemical and analytical procedures for $U$-Th measurements}

126 Selected areas of carbonate crust were hand-drilled carefully to obtain samples of 127 between $\sim 50-500 \mathrm{mg}$. Carbonate samples were collected at different depths across a 128 cross-cut section of NL7-CC2 crust. Carbonate crusts are typically highly 129 heterogeneous and samples of this size (referred to as 'bulk' samples in the following 130 text) are contaminated by detrital material, complicating U-Th dating. To try to reduce 131 such contamination, some carbonate samples were also collected using a computer132 assisted microsampling device (MicroMill, New Wave Research). This system 
133 enables accurate sampling of sub-millimeter areas of polished sections. For those

134 small carbonate samples (referred to as 'micromilled' samples subsequently), sampling

135 areas were selected using scanning electron microscopy and/or electron microprobe

136 analyzer. Great care was taken to avoid sampling of detrital grains (i.e. quartz),

137 biogenic components and cavities (e.g. fossil emplacements of tubeworms), which

138 may be filled with late-stage aragonite (Fig. 1). About $1 \mathrm{mg}$ of carbonate powder

139 was collected for each of those micromilled samples for U-Th analysis.

141 To assess the composition of the detrital end-member and thereby allow an isochron 142 approach, two sediment samples were analysed which were collected using 143 submersible-mounted corers in the studied area, but away from active zones of fluid 144 seepage. These samples - NL14-PC1 and NL7-BC1 - were recovered at $\sim 2120 \mathrm{~m}$ and $1451620 \mathrm{~m}$ water depths, respectively, and are reddish-brown foraminiferal and pteropod 146 oozes. The average of their U-series composition was assumed to be representative of 147 the sediment fraction incorporated within the carbonate crust.

149 Each sample (i.e. bulk, micromilled, sediment) was dissolved slowly in $7.5 \mathrm{M} \mathrm{HNO}_{3}$ 150 and spiked with a mixed ${ }^{236} \mathrm{U} /{ }^{229}$ Th spike (Robinson et al., 2002). Any undissolved 151 detrital fractions were transferred into cleaned Teflon vessels and fully digested with a 152 mixed (3:1) HF:HCl solution before being added back into corresponding supernatants. 153 Samples were evaporated, taken up with 7.5M $\mathrm{HNO}_{3}$, and diluted with ultrapure water. $154 \mathrm{U}$ and $\mathrm{Th}$ were then co-precipitated onto Fe-oxides after addition of $5 \mathrm{mg}$ (2.5 $\mathrm{mg}$ for 155 micromilled samples) of ultrapure Fe and precipitation with ammonia. After 24 hours, 156 Fe-oxides were centrifuged, cleaned several times in ultrapure water and dissolved in 157 7.5 $\mathrm{M} \mathrm{HNO}_{3}$. Finally, $\mathrm{U}$ and Th were separated chemically using conventional anion 158 exchange techniques adapted from previous studies (Edwards et al., 1986). The 159 volumes of anion-exchange resin and acids used for separating U-Th were much 160 smaller for micromilled samples than for bulk and sediment samples. Typical 161 procedural blanks were $1.2 \times 10^{-10} \mathrm{~g}{ }^{238} \mathrm{U}$ and $3.0 \times 10^{-11} \mathrm{~g}{ }^{232} \mathrm{Th}$ for bulk carbonate and 162 sediment samples, and $1.0 \times 10^{-11} \mathrm{~g}{ }^{238} \mathrm{U}$ and $1.3 \times 10^{-12} \mathrm{~g}{ }^{232} \mathrm{Th}$ for micromilled samples.

163 Total $\mathrm{U}$ and Th procedural blanks were small compared to final sample concentrations.

$165 \mathrm{U}$ and Th concentrations and isotope ratios were measured with a MC-ICPMS (Nu 166 Plasma). Procedures largely follow those described in Robinson et al. (2002). The 
167 external reproducibility on the ${ }^{234} \mathrm{U} /{ }^{235} \mathrm{U}$ ratio was assessed by repeatedly measuring 168 the CRM-145 standard during each session using a standard-bracketing measurement 169 protocol (Robinson et al., 2002), and was $1.7 \%$ (2 s.d.) for sediment and bulk 170 carbonate samples and ranged from 2.7 to $8.3 \%$ o for the mg-sized carbonate samples. 171 Th was measured with ${ }^{229} \mathrm{Th}$ and ${ }^{230} \mathrm{Th}$ sequentially in a single ion-counter equipped 172 with an energy filter to improve abundance sensitivity, and ${ }^{232}$ Th in a Faraday collector. 173 Mass discrimination and ion-counter gain were assessed by bracketing Th samples 174 with CRM-145 U measurements. Internal precision obtained on measured ${ }^{229} \mathrm{Th} /{ }^{230} \mathrm{Th}$ 175 ratios was always better than $5 \%$ o for sediment and bulk carbonate samples, and better 176 than $50 \%$ o for the smaller micromilled samples. Previous assessment of this 177 measurement approach using TIMS calibrated in-house Th standards (e.g. Robinson et 178 al. 2002) has indicated its accuracy, and that internal precisions are a reasonable 179 assessment of external repeatability at the low signal intensities used in this study.

181 Carbonate ages were corrected for detrital contamination by assuming that the mean 182 composition of the modern local sediment well represents the initial detrital 183 component for all samples. Ages were calculated from the measured $\left({ }^{232} \mathrm{Th} /{ }^{238} \mathrm{U}\right)$, $184\left({ }^{230} \mathrm{Th} /{ }^{238} \mathrm{U}\right),\left({ }^{234} \mathrm{U} /{ }^{238} \mathrm{U}\right)$ of each sample and these ratios in the average sediment value 185 using a two-point isochron approach, calculated in 3D using the ISOPLOT program (v. 1863.34 , Ludwig, 2003) and half lives following Cheng et al. $(2000), \lambda_{230 \mathrm{Th}}=9.158 \times 10^{-6}$ $\mathrm{yr}^{-1}, \lambda_{232 \mathrm{Th}}=4.95 \times 10^{-11} \mathrm{yr}^{-1}, \lambda_{234 \mathrm{U}}=2.826 \times 10^{-6} \mathrm{yr}^{-1}$ and $\lambda_{238 \mathrm{U}}=1.551 \times 10^{-10} \mathrm{yr}^{-1}$.

188 Uncertainty in the isotopic composition of the sediment end-member was assumed to 189 correspond to the standard deviation (2SD) of the measured $\left({ }^{232} \mathrm{Th} /{ }^{238} \mathrm{U}\right),\left({ }^{230} \mathrm{Th} /{ }^{238} \mathrm{U}\right)$ 190 and $\left({ }^{234} \mathrm{U} /{ }^{238} \mathrm{U}\right)$ activity ratios for the two sediments analysed.

\section{Results}

\subsection{Major element data}

196 Electron microprobe $\mathrm{Sr} / \mathrm{Ca}$ ratios vary from $\sim 0.001$ to 0.040 , and $\mathrm{Mg} / \mathrm{Ca}$ ratios from

1970.0 to 0.3 (Fig. 3A,B). Down-crust variation of $\mathrm{Sr} / \mathrm{Ca}$ and $\mathrm{Mg} / \mathrm{Ca}$ is due to changes in 198 mineralogy, being controlled by the relative contribution of Sr-rich aragonite, Mg-rich 199 carbonate phases, low-Mg calcite, and detritus (Bayon et al., 2007). Sr/Ca ratios are 200 most typically around 0.020 , which indicates the predominance of aragonite in the 
201 crust (Bayon et al., 2007). Sr/Ca and $\mathrm{Mg} / \mathrm{Ca}$ values are both low in the upper part of

202 the studied section (i.e. the top $0.4 \mathrm{~cm}$ ) reflecting the presence of low-Mg calcite in the 203 bivalve shells (Fig. 3B). Below this upper layer, the frequency of high $\mathrm{Mg} / \mathrm{Ca}$ values 204 increases progressively with depth, indicating enhanced contribution from high-Mg 205 carbonate phases. Detrital contents in crust NL7-CC2, inferred from both electron 206 microprobe and XRF data (Table 1), can be as high as $12 \mathrm{wt} \%$, increasing 207 progressively with depth (Fig. 3C).

\section{4.2. U-series data}

210 Uranium concentrations vary from $\sim 1$ to $20 \mathrm{ppm}$ for carbonate samples (bulk and 211 micromilled) and average $1.3 \mathrm{ppm}$ in the two sediment samples (Table 2). These 212 carbonate concentrations are comparable to those reported in the literature for other 213 cold seep carbonates (Teichert et al., 2003; Watanabe et al., 2008). The average ${ }^{238} \mathrm{U}$ 214 concentration in crust NL7-CC2 increases progressively with depth, from $\sim 3.5 \mathrm{ppm}$ for 215 the uppermost centimetre, to $\sim 9.6 \mathrm{ppm}$ for the middle part (from $1 \mathrm{~cm}$ to $4.3 \mathrm{~cm}$-depth) 216 and $\sim 20.8$ ppm for the bottom part of the crust.

$218{ }^{232}$ Th concentrations range from $\sim 30$ to $2100 \mathrm{ppb}$ in carbonates and are 4200 and 5000 219 ppb in the two sediments. Carbonate $\left({ }^{230} \mathrm{Th} /{ }^{232} \mathrm{Th}\right)$ ratios are low compared to many 220 natural carbonates (from 2.6 to 11.5 , Table 2), due to the young age (low ${ }^{230} \mathrm{Th}$ 221 ingrowth), but also, more importantly, to detrital contamination (high initial ${ }^{232} \mathrm{Th}$ ). 222 The mean $\left({ }^{238} \mathrm{U} /{ }^{232} \mathrm{Th}\right)$ value for the two sediments is $0.87 \pm 0.02$, which is typical of 223 detrital sediments and river suspended particles (e.g. Vigier et al., 2001; Ludwig and 224 Paces, 2002; Dosseto et al., 2006a,b). Sediment $\left({ }^{230} \mathrm{Th} /{ }^{232} \mathrm{Th}\right)$ ratios are significantly 225 higher ( 2.3) than secular equilibrium (Table 3), due to addition of excess ${ }^{230} \mathrm{Th}$ from 226 seawater.

228 On a $\left({ }^{230} \mathrm{Th} /{ }^{232} \mathrm{Th}\right)$ vs. $\left({ }^{238} \mathrm{U} /{ }^{232} \mathrm{Th}\right)$ isochron diagram (i.e. a Rosholt-type diagram), the 229 carbonate samples from crust NL7-CC2 plot well within the range of published data 230 for other cold seep carbonates (Fig. 4B). Micromilled carbonate samples exhibit $231\left({ }^{230} \mathrm{Th} /{ }^{232} \mathrm{Th}\right)$ and $\left({ }^{238} \mathrm{U} /{ }^{232} \mathrm{Th}\right)$ ratios higher than bulk carbonate crust samples (Fig 4A) 232 indicating that micromilling has been successful, to some extent, in separating 233 carbonate phases from detrital-rich areas within carbonate crust. For all the carbonate 234 samples reported in this study, however, both major element and U-Th data clearly 
235 show that detrital contamination is too high to allow calculation of simple ${ }^{230} \mathrm{Th} / \mathrm{U}$ ages,

236 and a correction for initial detrital content is required.

238 Measured $\left({ }^{234} \mathrm{U} /{ }^{238} \mathrm{U}\right.$ ) ratios (Table 2) are quoted as initial $\delta^{234} \mathrm{U}$ values, corrected for 239 detrital contamination and decay of excess ${ }^{234} U$ since sample formation (Table 3),

240 where $\delta^{234} U$ represents the deviation in permil of $\left({ }^{234} U /{ }^{238} U\right)$ from its secular 241 equilibrium value of 1.000: $\delta^{234} U=\left[\left\{\left({ }^{234} U /{ }^{238} U\right)_{\text {meas }} /\left({ }^{234} U /{ }^{238} U\right)_{\text {equ }}\right\}-1\right] \times 10^{3}$. $)$

242 Initial $\delta^{234} U$ values range from 130 to 153 , and all samples exhibit, within error, values

243 close to modern seawater (146.6 $\pm 2.5 \%$; Robinson et al., 2004). This indicates that

244 the carbonate bound $U$ is likely to be derived from seawater rather than from pore 245 waters; this latter U-pool being typically characterized by much higher $\delta^{234} \mathrm{U}$ (Cochran 246 et al., 1986; Gariepy et al., 1993; Henderson et al., 1999).

\section{5. Discussion}

\subsection{Detrital versus hydrogenous source of initial ${ }^{230} \mathrm{Th}$}

The high $\left({ }^{230} \mathrm{Th} /{ }^{232} \mathrm{Th}\right)$ ratios measured in sediments provide clear evidence for two possible sources of initial ${ }^{230} \mathrm{Th}$ : supported ${ }^{230} \mathrm{Th}$ within the detrital grains, and excess ${ }^{230}$ Th scavenged to the grain-surfaces from seawater. Any assumption that initial Th

255 has a typical crustal $\left({ }^{230} \mathrm{Th} /{ }^{232} \mathrm{Th}\right)$ would therefore lead to errors in calculated ages.

256 This indicates the need to measure the sediment end-member directly to improve age accuracy when dating carbonate crusts.

259 The presence of two sources of initial ${ }^{230}$ Th raises the possibility that the mixture of 260 these two sources might change with time, making the use of a constant initial 261 composition inappropriate. Changes in the $\left({ }^{230} \mathrm{Th} /{ }^{232} \mathrm{Th}\right)$ of the sediment material 262 accumulating on the seafloor may occur. However, ${ }^{230} \mathrm{Th}$ is scavenged rapidly after its 263 formation in seawater (Henderson et al. 1999), so the flux of ${ }^{230} \mathrm{Th}$ to the sediment 264 should remain largely unchanged at any one site. Significant changes in the flux of 265 detrital ${ }^{232} \mathrm{Th}$ would therefore be required to alter the sedimenting $\left({ }^{230} \mathrm{Th} /{ }^{232} \mathrm{Th}\right)$ and,

266 although these may occur on longer timescales, they are unlikely within the Holocene 267 period in which crust NL7-CC2 grew. Another issue is that after carbonate 268 precipitation and incorporation of the sediment in the crust, the ${ }^{230} \mathrm{Th}$ excess in the 
269 sediment component then starts to decay towards equilibrium. Formally, this would 270 need to be corrected for the age calculation. However, because the studied carbonate 271 samples are relatively young, the decay of sediment-bound ${ }^{230} \mathrm{Th}$ is small compared to 272 the existing $2 \mathrm{~s}$ uncertainty on the $\left({ }^{230} \mathrm{Th} /{ }^{232} \mathrm{Th}\right)$ value for the sediment end-member, 273 and hence, can be neglected.

A potentially more significant mechanism to alter the mixture of detrital and scavenged Th initially present is by the direct scavenging of seawater Th to the crust surface. Some assessment of the magnitude of this process can be derived by considering the ${ }^{232} \mathrm{Th}$ budget of the crust samples. By assuming that ${ }^{232} \mathrm{Th}$ in each sample is entirely within detrital particles, a maximum ${ }^{232} \mathrm{Th}$ concentration of the detrital particles can be calculated for each sample. This calculation is performed using detrital fractions calculated with the bulk chemical data for each sample (Fig. 3C) and measured ${ }^{232} \mathrm{Th}$ concentrations (Table 2). The calculation indicates maximum detrital ${ }^{232} \mathrm{Th}$ concentrations for all but the uppermost sample of $\sim 6$ to $20 \mathrm{ppm}$. This range is in good agreement with the detrital Th contents of the two studied sediment samples ( 15 ppm, as estimated on a carbonate-free basis; Table 1), and close to average shale composite Th concentrations (12.3 ppm for NASC - Condie, 1993; 14.6 ppm for PAAS - Taylor and McLennan, 1985). This suggests that there is negligible additional scavenging of ${ }^{232} \mathrm{Th}$ directly to the crust, and that correction for seawaterderived ${ }^{232} \mathrm{Th}$ is not necessary. The exception is the uppermost crust sample $(0 \mathrm{~cm})$ which yields an estimated maximum detrital ${ }^{232} \mathrm{Th}$ concentration of $\sim 175 \mathrm{ppm}$, much 292 the crust surface directly from seawater. Hydrogenous Fe-oxide deposits are typically 293 highly enriched in Th (e.g. Henderson and Burton 1999) and the Fe-oxide layer 294 covering NL7-CC2 probably hosts this seawater-derived Th. Using simple mass 295 balance considerations, the proportion of the hydrogenous component in the uppermost 296 carbonate sample and its Th isotopic composition can be calculated (see Appendix for 297 details of calculation). This calculation indicates that the hydrogenous Fe-oxide 298 component is characterized by a $\left({ }^{230} \mathrm{Th} /{ }^{232} \mathrm{Th}\right)$ ratio of $\sim 3.1$, in agreement with activity 299 ratios measured in the western Mediterranean Sea at similar water depths (Roy300 Barman et al., 2002). It also shows that $\sim 60 \%$ of ${ }^{232} \mathrm{Th}$ in the uppermost crust sample 301 has been scavenged from seawater, whereas the remaining $\sim 40 \%$ derives from 302 sediment incorporated within the carbonate matrix (see Appendix). 
304 Clearly, the isochron age calculated for the topmost sample $(9.2 \pm 2.5 \mathrm{ka}$; Table 1$)$ is

305 overestimated due to presence of initial hydrogenous ${ }^{230} \mathrm{Th}$ and, hence, is discarded in 306 the discussion below. The ${ }^{232}$ Th budget calculations suggest however that other crust

307 samples have not been exposed significantly to seawater scavenging.

\subsection{Validity of calculated ages and age uncertainties}

The age calculated for the base of the NL7-CC2 crust using the high ${ }^{230} \mathrm{Th} /{ }^{232} \mathrm{Th}$ value of local sediment to correct for initial Th is $0.8 \pm 1.3 \mathrm{ka}$ (Table 3), which

313 suggests that carbonate precipitation, and hence fluid seepage, is probably still active 314 at the studied site. This agrees with evidence that dense bushes of vestimentiferan 315 tubeworms live at present underneath carbonate pavements in this area (Bayon et al., 316 In press), providing re-assurance for the validity of the dating approach, and for the suitability of the sediment end-member values used for calculations. Using an endmember with typical crustal values, i.e. at secular equilibrium, would lead instead to a much older age of $\sim 5.2 \mathrm{kyr}$ BP for the base of the carbonate crust, in contradiction with in situ observation.

The two-point isochron method used in this study is convenient for acquiring a high-resolution age profile for such 'complex' carbonate archives. However, the uncertainty in the ages calculated with this method depends crucially on the errors assigned to the sediment end-member used for calculations. In this study, the uncertainty in the end-member isotopic composition was taken as the standard

$328\left({ }^{230} \mathrm{Th} /{ }^{232} \mathrm{Th}\right)$ sediment ratio, this corresponds to a value of $2.31 \pm 0.46$. Considering a 329 less conservative error $( \pm 1 \mathrm{SD})$ on the sediment U/Th ratios would lead to smaller error 330 bars on calculated isochron ages, such as $2.12 \pm 0.84 \mathrm{ka}$ for the sample drilled at $1 \mathrm{~cm}$ 331 depth (instead of $2.1 \pm 1.5 \mathrm{ka}$ ), and $0.84 \pm 0.64 \mathrm{ka}$ for the sample drilled at $5 \mathrm{~cm}$-depth 332 (instead of $0.8 \pm 1.3 \mathrm{ka}$ ).

334 In order to further assess the suitability of our sediment end-member for calculating 335 isochron ages, its composition was determined indirectly by performing additional 3-D 336 isochron calculations on several sets of carbonate samples drilled at similar depths of 
337 NL7-CC2 crust (hence assumed to have a similar age). This approach uses the 338 intercept of each isochron to calculate the ${ }^{232} \mathrm{Th}$-free ratios of $\left({ }^{230} \mathrm{Th} /{ }^{238} \mathrm{U}\right)$ and $339\left({ }^{234} \mathrm{U} /{ }^{238} \mathrm{U}\right)$ required for the age calculation, but also estimates the present-day $340\left({ }^{230} \mathrm{Th} /{ }^{232} \mathrm{Th}\right)$ ratio of the detrital sediment end-member. The isochron derived for the 341 two bottommost samples of the crust, drilled at $5 \mathrm{~cm}$ and $5.5 \mathrm{~cm}$-depth, yields a 342 sediment end-member with $\left({ }^{230} \mathrm{Th} /{ }^{232} \mathrm{Th}\right)=2.2 \pm 0.4(2 \mathrm{SD})$. Another isochron was

343 derived for the samples drilled at $3.6 \mathrm{~cm}$ and $4.3 \mathrm{~cm}$-depth, which provides a $344\left({ }^{230} \mathrm{Th} /{ }^{232} \mathrm{Th}\right)$ of $2.4 \pm 1.0$. Finally, the isochron derived for the three samples collected 345 at $\sim 2.5 \mathrm{~cm}$-depth gives a detrital $\left({ }^{230} \mathrm{Th} /{ }^{232} \mathrm{Th}\right)$ of $1.92 \pm 0.12$. All those independently 346 calculated $\left({ }^{230} \mathrm{Th} /{ }^{232} \mathrm{Th}\right)$ ratios agree well with the mean $\left({ }^{230} \mathrm{Th} /{ }^{232} \mathrm{Th}\right) \pm 2 \mathrm{SD}$ value 347 obtained from the analysis of our two sediments $(2.31 \pm 0.46)$, providing further 348 reassuring evidence for the suitability of the sediment end-member values and 349 associated errors used for calculations. This shows that the two-point isochron ages 350 calculated with our approach can be considered as robust.

\subsection{U-Th isotope stratigraphy}

354 The ${ }^{230} \mathrm{Th} / \mathrm{U}$ age-depth profile for NL7-CC2 shows that the carbonate crust has grown downward since about $5 \pm 1$ ka (Fig. 3E). Previous studies suggested on theoretical grounds that carbonate crusts at cold seeps may grow downward into the sediment (Paull et al., 1992; Greinert et al., 2002; Aloisi et al., 2002), but our results represent the first direct evidence for this mode of formation. The average growth rate for crust NL7-CC2 is $\sim 1.1 \mathrm{~cm} / \mathrm{kyr}$. In detail, however, three distinct periods of carbonate formation can be distinguished from top to bottom, with average growth rates of $\sim 0.4 \mathrm{~cm} / \mathrm{kyr}$ for the upper first centimetre, $\sim 5 \mathrm{~cm} / \mathrm{kyr}$ for the next four $\mathrm{cm}$, and $0.8 \mathrm{~cm} / \mathrm{kyr}$ for the bottom $\mathrm{cm}$ of the crust, respectively (Fig. 3E).

As discussed earlier, the relatively large error bars associated to calculated 366 sediment end-member composition. However, although the $\left({ }^{230} \mathrm{Th} /{ }^{232} \mathrm{Th}\right)$ of the sediment end-member is not known with accuracy, it is not likely to vary much on the small spatial scale involved in the studied crust. Instead, the detritus at this particular

369 site is most probably characterized by a more constant composition. This suggests that 370 the age of one piece of the crust relative to another is much better known in relative 
371 terms that by taking the difference in the two absolute ages. Hence, we are confident

372 that the changes in growth rate in the crust reported above and discussed below 373 (section 5.5) are robust, at least when described in relative terms.

\subsection{A record of progressive sulphate depletion}

The age-depth profile is compared to profiles for carbonate $\delta^{13} \mathrm{C}$ and carbonate mineralogy (Gontharet et al., 2007), $\mathrm{Sr} / \mathrm{Ca}$ and $\mathrm{Mg} / \mathrm{Ca}$ (Fig. 2). $\mathrm{Sr} / \mathrm{Ca}$ and $\mathrm{Mg} / \mathrm{Ca}$ ratios show opposite vertical trends, indicating a gradual downward change from aragonite to high-Mg-rich carbonate phases. A similar mineralogical trend was reported for a carbonate crust collected from the Amsterdam mud volcano in the eastern Mediterranean basin (Aloisi et al., 2002). In the absence of any microscopic evidence for re-crystallisation of aragonite into high-Mg calcite, this trend is best explained by a change in chemical conditions (Aloisi et al., 2002). Previous studies have shown that aragonite precipitation is favoured over that of high-Mg calcite at high $\mathrm{SO}_{4}{ }^{2-}$ concentrations (e.g. Burton and Walker, 1987; Burton, 1993), whereas high-Mg carbonates generally precipitate from pore waters with low dissolved $\mathrm{SO}_{4}{ }^{2-}$ contents, typically at the interface between methane and sulphate (Luff and Wallman, 2003; Luff et al., 2004; Gieskes et al., 2005). Our geochemical data therefore suggest that the mineralogical trend from aragonite to high-Mg carbonates in crust NL7-CC2 was induced by a progressive depletion in dissolved sulphate.

In anoxic or suboxic conditions, it is well known that $U$ is reduced from its 394 concentrations across NL7-CC2 (see Table 2), indicating increasing U concentrations 395 from top to bottom, therefore would also suggest that a gradual change in chemical 396 conditions occurred during the formation of the crust. This is further supported by the 397 down-crust $\delta^{13} \mathrm{C}$ profile (Fig. 3D). Methane-rich fluids on continental margins are 398 characterized by $\delta^{13} \mathrm{C}$ values $\left(\delta^{13} \mathrm{C}\right.$ from $\sim-110$ to $-30 \%$ ) much lower than seawater $399\left(\delta^{13} \mathrm{C} \sim 1 \%\right.$ ) . Hence, the progressive downward depletion in carbonate ${ }^{13} \mathrm{C}$ in crust 400 NL7-CC2 indicates an increasing contribution from AOM-derived versus seawater401 derived carbon in the lower part of the crust (Gontharet et al., 2007). Overall, these 402 data point clearly toward a progressive isolation of the growing crust from seawater 
403 through time. This is consistent with the downward growth of the crust indicated by

404 the U/Th chronology.

\subsection{Carbonate precipitation rates}

407 Interestingly, variations in mineralogy across crust NL7-CC2 coincide relatively 408 well with the changes in growth rates determined from the age-depth profile (Fig. 3).

409 In particular, the transition between aragonite and high-Mg calcite in the lower part of 410 the crust corresponds to a shift from fast $(\sim 5 \mathrm{~cm} / \mathrm{kyr})$ to slow $(\sim 0.8 \mathrm{~cm} / \mathrm{kyr})$ period of 411 carbonate formation (Fig. 3E). Growth rates can be converted into carbonate 412 precipitation rates using the bulk crust density $\left(1.6 \mathrm{~g} \mathrm{~cm}^{3}\right)$. The carbonate precipitation 413 rates corresponding to the three growth periods in NL7-CC2 average $\sim 6 \mu \mathrm{mol} \mathrm{cm} \mathrm{a}^{-1}$ 414 for the topmost part of the crust, $\sim 80 \mu \mathrm{mol} \mathrm{cm}{ }^{2} \mathrm{a}^{-1}$ for the middle part, and $\sim 12 \mu \mathrm{mol}$ $415 \mathrm{~cm}^{2} \mathrm{a}^{-1}$ for the high-Mg carbonate part of the crust. Using dimensions commonly used 416 in experimental studies $\left(\mu \mathrm{mol} \mathrm{m} \mathrm{m}^{-1}\right.$ ), those carbonate precipitation rates yield $\sim 7,92$ 417 and $14 \mu \mathrm{mol} \mathrm{m} \mathrm{m}^{-1}$, respectively. The average rate of precipitation estimated for the 418 high-Mg carbonate layer $\left(14 \mu \mathrm{mol} \mathrm{m} \mathrm{m}^{2} \mathrm{~h}^{-1}\right)$ is consistent with rates determined

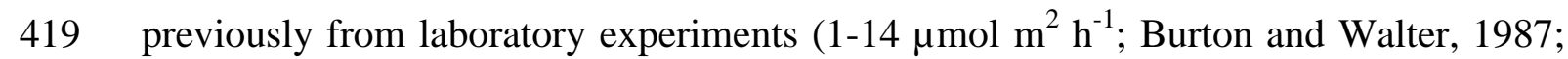
420 Zhong and Mucci, 1993) and numerical modeling of biogeochemical processes at cold

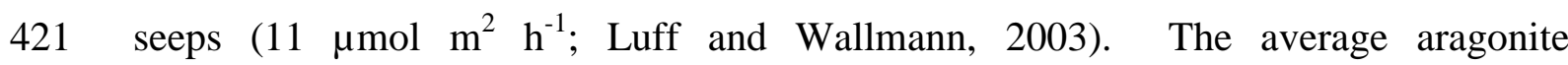
422 precipitation rate calculated for the middle part of the crust $\left(\sim 92 \mu \mathrm{mol} \mathrm{m}{ }^{2} \mathrm{~h}^{-1}\right)$ is in 423 agreement with the kinetic constant derived from modeling by Luff and Wallmann $424\left(114 \mu \mathrm{mol} \mathrm{m} \mathrm{m}^{-1}\right)$, but higher than experimental values $\left(22-41 \mu \mathrm{mol} \mathrm{m}{ }^{2} \mathrm{~h}^{-1}\right.$; Burton 425 and Walter, 1987). This finding hence would confirm the existing literature 426 indications that aragonite precipitates much faster at cold seeps than during abiotic 427 laboratory experiments.

\subsection{Controls on carbonate crust formation at cold seeps}

430 Several parameters are known to affect carbonate formation at cold seeps, including 431 sedimentation rates, bioturbation, bioirrigation, and upward methane fluxes (see Luff 432 et al., 2004; Luff and Wallmann, 2004). The fact that the 5000 year-old NL7-CC2 433 crust is still exposed on the seafloor at present suggests that particles sedimenting on 434 the seafloor at the studied location have been eroded with time, and hence that changes 435 in sedimentation rates have not played a significant role in controlling the formation of 436 the crust. 
438 At the onset of fluid seepage, an initial $\mathrm{cm}$-thick layer of aragonite may precipitate 439 relatively rapidly, in just a few hundred years (Luff et al., 2005). The same authors 440 have suggested that subsequent development of carbonate crust is limited by high 441 bioturbation activity. The presence of large fragments of chemosynthetic bivalves in 442 the topmost part of NL7-CC2 crust suggests that bioturbation was active $\sim 5$ kyr ago, 443 during the initial stage of carbonate precipitation (Fig. 5A). At that time, the initiation 444 of fluid venting probably led to development of vent communities and associated 445 bioturbation processes in the near-seafloor environment. Most likely, this initial stage 446 of carbonate crust formation led to pore space clogging, reduced fluid venting and 447 associated development of macro-benthos communities supported by chemosynthesis, 448 all of which would have resulted in a significant drop of bioturbation at the studied 449 location (Fig. 5B). It is possible that the absence of bioturbation resulted in enhanced 450 carbonate precipitation, thereby explaining the differences in aragonite growth rates 451 observed in the topmost layer of crust NL7-CC2, from slow (average $7 \mu \mathrm{mol} \mathrm{m} \mathrm{h}^{-1}$ ) to 452 fast $\left(\sim 92 \mu \mathrm{mol} \mathrm{m} \mathrm{h}^{-1}\right)$ rates.

454 Certainly, the development of an aragonite crust near the sediment surface would 455 have affected the exchange of dissolved species between sediment and bottom water, 456 leading to reduced supply of $\mathrm{CH}_{4}$ and lower AOM rates. As a consequence, as less 457 bicarbonate is supplied to pore water via AOM, dissolution of aragonite may start after 458 the initial stage of carbonate crust formation. Using numerical simulations, Luff et al. 459 (2005) suggested that aragonite dissolution may prevail over precipitation at this stage, 460 at least temporarily. Then, after the initial aragonite layer has become thinner, higher 461 flow velocity allows again for enhanced upward transport of methane, inducing in turn 462 precipitation of aragonite and calcite at the base of the initial aragonite crust (Luff et 463 al., 2005). A new maximum in AOM rates and aragonite precipitation can hence be 464 attained, which leads to the formation of a new aragonite-rich layer, about 2000 yrs 465 after the initial stage of carbonate precipitation (Fig. 5B). Those results from 466 numerical modeling agree well with the mineralogical and geochemical downward 467 changes observed in crust NL7-CC2. Therefore, the lower rates of carbonate 468 precipitation observed for the top part of the crust could also reflect, at least to some 469 degree, a temporary episode of aragonite dissolution that followed the initial stage of 470 carbonate crust formation $\sim 5000$ years ago. 
472 One of the most prominent results of this study is the gradual $\mathrm{SO}_{4}{ }^{2-}$ depletion at the

473 studied location inferred from $\delta^{13} \mathrm{C}, \mathrm{Sr} / \mathrm{Ca}$ and $\mathrm{Mg} / \mathrm{Ca}$ data, which could result either

474 from enhanced upward methane fluxes and/or a reduction of the dissolved sulphate

475 transport to the base of the crust. Although a change in the upward $\mathrm{CH}_{4}$ flux is

476 possible, it is very likely that the downward flux of seawater sulphate has dropped with

477 time. In carbonate-paved areas, bioirrigation is an important factor controlling the

478 solute exchange between bottom-waters and underlying sediments, in which

479 macrobenthic organisms actively pump water into the sediment. At the studied

480 location, the presence of dense bushes of vestimentiferan tubeworms must have

481 sustained an active and continuous inflow of seawater sulphate over the last thousand

482 years, which allowed high AOM turnover and fast aragonite precipitation at the base of

483 crust (Fig. 5B). However, with time, it is likely that the efficiency of this biological 484 pump has decreased, most probably in response to progressive clogging due to intense 485 carbonate formation (Fig. 5C).

\section{Concluding remarks}

489 The application of U-series to methane-derived authigenic carbonates adds unique 490 temporal information to the study of biogeochemical processes related to anaerobic 491 oxidation of methane (AOM) on continental margins. U-Th ages require correction for 492 appreciable initial Th content, and we have shown that this is more appropriately 493 performed using the U-Th composition of local sediment containing excess ${ }^{230} \mathrm{Th}$ from 494 seawater, than with typical crustal U-Th values. Dating of a crust from the Nile deep495 sea fan demonstrates clearly something previously suspected - that crusts grow 496 downwards with time from the sediment surface - in this case over a period of $\sim 5 \mathrm{kyr}$. 497 This chronology also allows carbonate precipitation rates to be estimated. Calculated 498 rates for average aragonite formation are about six-time higher than for high-Mg 499 calcite. In agreement with numerical studies, aragonite precipitates much faster at cold 500 seeps than during abiotic laboratory experiments, due most probably to microbial 501 catalysis. Our results also highlight the role played by chemosynthetic macro-benthos 502 at cold seeps in the formation of cold seep carbonates, through transport of seawater 503 sulphate available for AOM (i.e. bioirrigation). Comparison of ${ }^{230} \mathrm{Th} / \mathrm{U}$ ages with 504 other data (mineralogy, $\delta^{13} \mathrm{C}, \mathrm{Sr} / \mathrm{Ca}, \mathrm{Mg} / \mathrm{Ca}$ ) suggests that both carbonate mineralogy 
505 and precipitation rates are closely related to the efficiency of this biological pump 506 through time.

\section{Acknowledgements}

510 The Nautinil expedition was funded by Ifremer, as part of the MEDIFLUX Project 511 (EUROMARGINS-ESF programme). We thank the captain, the officers and crews of $512 \mathrm{R} / \mathrm{V}$ Atalante, the pilots and technicians of Nautile, and the members of the Nautinil 513 scientific parties for their assistance at sea. J. Etoubleau (Ifremer) is thanked for XRF

514 data. A. Mason and N. Charnley (U. Oxford) are thanked for assistance during U/Th 515 analyses and SEM work, respectively. Two anonymous reviewers are acknowledged 516 for providing thoughtful and constructive reviews, which improve significantly our 517 manuscript. 
Appendix: Calculation of the proportion of the hydrogenous component in the uppermost carbonate crust sample and of its $\left.{ }^{230} \mathrm{Th} /{ }^{232} \mathrm{Th}\right)$ composition balance equations:

$$
\begin{aligned}
& { }^{232} \mathrm{Th} \text { total }={ }^{232} \mathrm{Th} \text { sediment } \cdot \mathrm{x}+{ }^{232} \mathrm{Th} \text { hydrogenous } \cdot \mathrm{y}+{ }^{232} \mathrm{Th} \text { carbonate } \cdot \mathrm{z} \\
& { }^{230} \mathrm{Th} \text { total }={ }^{230} \mathrm{Th} \text { sediment } \cdot \mathrm{x}+{ }^{230} \mathrm{Th} \text { hydrogenous } \cdot \mathrm{y}+{ }^{230} \mathrm{Th} \text { carbonate } \cdot \mathrm{z} \\
& { }^{238} \mathrm{U}_{\text {total }}={ }^{238} \mathrm{U}_{\text {sediment }} \cdot \mathrm{x}+{ }^{238} \mathrm{U}_{\text {hydrogenous }} \cdot \mathrm{y}+{ }^{238} \mathrm{U}_{\text {carbonate }} \cdot \mathrm{z}
\end{aligned}
$$

where ${ }^{230} \mathrm{Th}$ carbonate refers to the ${ }^{230} \mathrm{Th}$ accumulated by decay of $\mathrm{U}$ since the authigenic carbonate sample formed. The subscripts sediment and hydrogenous refer to the sediment and water-derived contributions, respectively, of ${ }^{232} \mathrm{Th},{ }^{230} \mathrm{Th}$ and ${ }^{238} \mathrm{U}$. Sediment values for ${ }^{232} \mathrm{Th}(4.68 \mathrm{ppm}),{ }^{230} \mathrm{Th}(58 \mathrm{ppt})$ and ${ }^{238} \mathrm{U}(1.33 \mathrm{ppm})$ are derived from the analyses of the two studied sediments. The subscript total refers to the measured concentrations of ${ }^{232} \mathrm{Th}(0.86 \mathrm{ppm}),{ }^{230} \mathrm{Th}(17.6 \mathrm{ppt})$ and ${ }^{238} \mathrm{U}(4.85 \mathrm{ppm})$ in the bulk carbonate sample. $x, y$ and $z$ represents the proportions of sediment, hydrogenous (Fe-oxides) and authigenic carbonate fractions, respectively. Microprobe measurements of the detritus content in the uppermost carbonate sample indicate that $x$ $\sim 0.005(0.5 \mathrm{wt} \%)$.

Assuming that ${ }^{232} \mathrm{Th}$ hydrogenous $=100 \mathrm{ppm}$ (Henderson and Burton, 1999) and ${ }^{232} \mathrm{Th}$ carbonate $=0$, the proportion $y$ of the hydrogenous component incorporated in the uppermost carbonate sample can be calculated from Eqn. 1: $y \sim 0.008$ (0.8 wt \%). This shows that $\sim 60 \%$ of ${ }^{232} \mathrm{Th}$ in this uppermost crust sample derives from the hydrogenous component (most probably associated to the Fe-oxide coating), whereas the remaining $\sim 60 \%$ of ${ }^{232} \mathrm{Th}$ derived from the sediment incorporated within the carbonate matrix.

Then, assuming that ${ }^{238} \mathrm{U}$ hydrogenous $=13 \mathrm{ppm}$ (Henderson and Burton, 1999), ${ }^{238} \mathrm{U}$ carbonate can be inferred using Eqn. 3: ${ }^{238} \mathrm{U}$ carbonate $~ 4.80 \mathrm{ppm}$.

Based on the ${ }^{230} \mathrm{Th} / \mathrm{U}$ age profile for crust NL7-CC2, it can be reasonably argued that the uppermost part of the crust formed about 5000 years ago. Using this age, one can use the ${ }^{230}$ Th age equation (Eqn. 4 ) to deduce ${ }^{230} \mathrm{Th}_{\text {carbonate }} \sim 4.2 \mathrm{ppt}$.

$\left({ }^{230} \mathrm{Th}\right.$ carbonate $/{ }^{238} \mathrm{U}$ carbonate $)=1-\mathrm{e}^{-\lambda 230 \mathrm{t}}+\left(\delta^{234} \mathrm{U}_{\mathrm{m}} / 1000\right) \cdot\left(\lambda_{230} /\left(\lambda_{230^{-}} \lambda_{234}\right) \cdot\left(1-\mathrm{e}^{-(\lambda 230-\lambda 234) \mathrm{t}}\right)\right.$ (4)

The value obtained for ${ }^{230} \mathrm{Th}$ carbonate can be inserted in Eqn. 2 to infer ${ }^{230} \mathrm{Th}$ hydrogenous $1650 \mathrm{ppt}$, and finally, $\left({ }^{230} \mathrm{Th} /{ }^{232} \mathrm{Th}\right)_{\text {hydrogenous }}=3.1$. 


\section{References}

Aloisi, G., Pierre, C., Rouchy, J.-M., Foucher, J.-P., Woodside, J., the MEDINAUT Scientific Party, 2000. Methane-related authigenic carbonates of eastern Mediterranean Sea mud volcanoes and their possible relation to gas hydrate destabilisation. Earth Planet. Sci. Lett. 184, 321-338.

Aloisi, G., Bouloubassi, I., Heijs, S.K., Pancost, R.D., Pierre, C., Sinninghe Damsté, J.S., Gottschal, J.C., Forney, L.J., Rouchy, J.-M., 2002. CH4-consuming microorganisms and the formation of carbonate crusts at cold seeps. Earth Planet. Sci. Lett. 203, 195-203.

Bayon, G., Pierre, C., Etoubleau, J., Voisset, M., Cauquil, E., Marsset, T., Sultan, N., Le Drezen, E., Fouquet, Y., 2007. $\mathrm{Sr} / \mathrm{Ca}$ and $\mathrm{Mg} / \mathrm{Ca}$ ratios in Niger Delta sediments: Implications for authigenic carbonate genesis in cold seep environments. Mar. Geol. 241, 93-109.

Bayon, G., Loncke, L., Dupré, S., Caprais, J.-C., Ducassou, E., Duperron, S., Etoubleau, J., Foucher, J.-P., Fouquet, Y., Gontharet, S., Henderson, G.M., Huguen, C., Klaucke, I., Mascle, J., Migeon, S., Olu-Le Roy, K., Ondréas, H., Pierre, C., Sibuet, M., Stadnitskaia, A., Woodside J., Fluid seepage on an unstable margin: The case of the Centre Nile fan. Mar. Geol, In press.

Bischoff, J.L., Fitzpatrick, J.A., 1991. U-series of impure carbonates: An isochron technique using total-sample dissolution. Geochim. Cosmochim. Acta 55, 543554.

Bohrmann, G., Meinert, J., Suess, E., Torres, M., 1998. Authigenic carbonates from the Cascadia subduction zone and their relation to gas hydrate stability. Geology $26,647-650$.

Burton, E.A., Walker, L.M., 1987. Relative precipitation rates of aragonite and Mg calcite from seawater: Temperature or carbonate ion control? Geology 15, 111-114. Burton, E.A., 1993. Controls on marine carbonate cement mineralogy: review and reassessment. Chem. Geol. 105, 163-179.

Cheng, H., Edwards, R.L., Hoff, J., Gallup, C.D., Richards, D.A., Asmeron, Y., 2000. The half-lives of ${ }^{234} \mathrm{U}$ and ${ }^{230} \mathrm{Th}$. Chem. Geol. 169, 17-33. 
Cochran, J.K., Carey, A.E., Sholkovitz, E.R., Surprenant, L.D., 1986. The 598 geochemistry of uranium and thorium in coastal marine sediments and sediment pore waters. Geochim. Cosmochim. Acta 50, 663-680.

600 Condie, K.C., 1993. Chemical composition and evolution of the upper continental crust: contrasting results from surface samples and shales. Chem. Geol. 104, 1-37.

Dosseto, A., Turner, S.P., Douglas, G.B., 2006. Uranium-series isotopes in colloids and suspended sediments: Timescale for sediment production and transport in the Murray-Darling River system. Earth Planet. Sci. Lett. 246, 418-431.

Dosseto, A., Bourdon, B., Gaillardet, J., Maurice-Bourgoin, L., Allègre, C.J., 2006. Weathering and transport of sediments in the Bolivian Andes: Time constraints from uranium-series isotopes. Earth Planet. Sci. Lett. 248, 759-771.

Edwards, R.L., Chen, J.H., Wasserburg, G.R., 1986. ${ }^{238}{ }^{2}-{ }^{234} \mathrm{U}_{-}{ }^{230}{ }^{T h}-{ }^{232}$ Th systematics and the precise measurement of time over the past 500,000 years. Earth Planet. Sci. Lett. 81, 175-192.

Edwards, R.L., Gallup, C.D., Cheng, H., 2003. Uranium-series dating of marine and lacustrine carbonates. Rev. Min. Geochem. 52, 363-405.

Gariepy, C., Ghaleb, B., Hillaire-Marcel, C., Mucci, A., Vallieres, S., 1993. Early diagenetic processes in Labrador Sea sediments: Uranium-isotope geochemistry. Can. J. Earth Sci. 31, 29-37.

Gieskes, J., Mahn, C., Day, S., Martin, J.B., Greinert, J., Rathburn, T., MacAdoo, B., 2005. A study of the chemistry of pore fluids and authigenic carbonates in methane seep environments: Kodiak Trench, Hydrate Ridge, Monterey Bay, and Eel River Basin. Chem. Geol. 220, 329-345.

Gontharet, S., Pierre, C., Blanc-Valleron, M.M., Rouchy, J.M., Fouquet, Y., Bayon, G., Foucher, J.P., Woodside, J., Mascle, J., the Nautinil scientific party, 2007. Nature and origin of the diagenetic carbonate crusts and concretions from mud volcanoes and pockmarks of the Nile deep-sea fan (eastern Mediterranean sea). Deep-Sea Research part II, in press.

Greinert, J., Bohrmann, G., Suess, E., 2001. Gas hydrate-associated carbonates and methane venting at Hydrate Ridge: Classification, distribution and origin of carbonate lithologies. In: Paull, C.K., Dillon, W.P. (Ed.), Natural Gas Hydrates: 
630 Greinert, J., Bohrmann, G., Elvert, M., 2002. Stromatolitic fabric of authigenic carbonate crusts: result of anaerobic methane oxidation at cold seeps in 4,850 water depth. Int. J. Earth. Sci. 91, 698-711.

Henderson, G.M. and Burton, K.W., 1999. Using $\left({ }^{234} \mathrm{U} /{ }^{238} \mathrm{U}\right)$ to assess diffusion rates of isotopic tracers in Mn crusts. Earth Planet. Sci. Lett., 170, 169-179.

Henderson, G.M., Slowey, N.C., Haddadluid, G.A., 1999. Fluid flow through

Henderson, G.M., Heinze, C., Anderson, R.F. and Winguth, A.M.E., 1999. Global distribution of the ${ }^{230} \mathrm{Th}$ flux to ocean sediments constrained by GCM modelling. Deep Sea Research, 46, 1861-1893.

Henderson, G.M., Slowey, N.C., Fleisher, M.Q., 2001. U-Th dating of carbonate platform and slope sediments. Geochim. Cosmochim. Acta 65, 2757-2770.

Hovland, M., Talbot, M.R., Qvale, H., Olaussen, S., Aasberg, L. 1987. Methane-

Lalou, C., Fontugne, M., Lallemand, S.E., Lauriat-Rage, A., 1992. Calyptogenarelated carbonate cements in pockmarks of the North Sea. J. Sedim. Petrol. 57, 881-892. cemented rocks and concretions from the eastern part of Nankai accretionary prism: Age and geochemistry of uranium. Earth Planet. Sci. Lett. 109, 419-429.

Lin, J.C., Broecker, W.S., Anderson, R.F., Hemming, S., Rubenstone, J.L., Bonani, G., 1996. New ${ }^{230} \mathrm{Th} / \mathrm{U}$ and ${ }^{14} \mathrm{C}$ ages from Lake Lahontan carbonates, Nevada, USA, and a discussion of the origin of initial thorium. Geochim. Cosmochim. Acta 60, 2817-2832.

Loncke, L., Gaullier, V., Mascle, J., Vendeville, B., Camera, L., 2006. The Nile deepsea fan : An example of interacting sedimentation, salt tectonics, and inherited subsalt paleotopographic features. Marine Petroleum Geology 23, 297-315.

Ludwig, K.R., 2003. Using Isoplot/Ex, Version 3, A geochronological toolkit for Microsoft Excel: Berkeley Geochronology Ctr. Spec. Pub. 4.

Ludwig, K.R., Paces, J. B., 2002. Uranium-series dating of pedogenic silica and carbonate, Crater Flat, Nevada. Geochim. Cosmochim. Acta 66, 487-506. 
660 Luff, R., Wallmann, K., 2003. Fluid flow, methane fluxes, carbonate precipitation and 661 biogeochemical turnover in gas hydrate-bearing sediments at Hydrate Ridge, 662 Cascadia Margin: numerical modelling and mass balances, Geochim. Cosmochim. Acta 67, 3403-3421.

664 Luff, R., Wallmann, K., Aloisi, G., 2004. Numerical modeling of carbonate crust 665 formation at cold vent sites: significance for fluid and methane budgets and chemosynthetic biological communities. Earth Planet. Sci. Lett. 221, 337-353.

Luff, R., Greinert, J., Wallmann, K., Klaucke, I., Suess, E., 2005. Simulation of long-

Mazzini, A., Ivanov, M. K., Parnell, J., Stadnitskaia, A., Cronin, B.T., Poludetkina, E., term feedbacks from authigenic carbonate crust formation at cold vent sites. Chem. Geol. 216, 157-174.

Luo, S.D., Ku, T.-L., 1991. U-series isochron dating: A generalized method employing total-sample dissolution. Geochim. Cosmochim. Acta 55, 555-564.

Mazurenko, L., van Weering, T.C.E., 2004. Methane-related authigenic carbonates from the Black Sea: geochemical characterisation and relation to seeping fluids. Mar. Geol. 212, 153-181.

Michaelis, W., Seifert, R., Nauhaus, K., Treude, T., Thiel, V., Blumenberg, M., Knittel, K., Geiseke, A., Peterknecht, K., Pape, T., Boetius, A., Amann, R., Jorgensen, B.B., Widdel, F., Peckmann, J., Pimenov, N.V., Gulin, M.B., 2002. Microbial reefs in the Black Sea fueled by anaerobic oxidation of methane. Science 297, 1013-1015.

Paull, C.K., Chanton, J.P., Neumann, A.C., Coston, J.A., Martens, C.S., 1992. Indicators of methane-derived carbonates and chemosynthetic organic carbon deposits: examples from the Florida escarpment. J. Soc. Sediment. Geol. Palaios 7, 361-375.

Reitner, J., Peckmann, J., Blumenberg, M., Michaelis, W., Reimer, A., Thiel, V., 2005. Concretionary methane-seep carbonates and associated microbial communities in Black Sea sediments. Palaeog., Palaeoclim. Palaeoecol. 227, 18-30.

Ritger, S., Carson, B., Suess, E., 1987. Methane-derived authigenic carbonates formed by subduction-induced pore-water expulsion along the Oregon/Washington margin. Geol. Soc. Am. Bull. 98, 147-156.

Robinson, L.F., Henderson, G.M., Slowey, N.C., 2002. U-Th dating of marine isotope stage 7 in Bahamas slope sediments. Earth Planet. Sci. Lett. 196, 175-187. 
692 Robinson, L.F., Belshaw, N.S., Henderson, G.M., 2004. U and Th concentrations and 693 isotope ratios in modern carbonates and waters from the Bahamas. Geochim. 694 Cosmochim. Acta 68, 1777-1789.

695 Roy-Barman, M., Coppola, L., Souhaut, M., 2002. Thorium isotopes in the western 696 Mediterranean Sea: an insight into the marine particle dynamics. Earth Planet. Sci. 697 Lett. 196, 161-174.

698 Stadnitskaia, A., Muyzer, G., Abbas, B., Coolen, M.J.L., Hopmans, E.C., Bass, M., van 699 Weering, T.C.E., Ivanov, M.K., Poludetkina, E., Sinninghe Damsté, J.S., 2005. 700 Biomarker and 16S rDNA evidence for anaerobic oxidation of methane and related carbonate precipitation in deep-sea mud volcanoes of the Sorokin Trough. Mar. Geol. 217, 67-96.

Taylor, S.R., McLennan, S.M., 1985. The continental crust: Its composition and evolution. Blackwell, Oxford, 312 pp.

Teichert, B.M.A., Eisenhauer, A., Bohrmann, G., Haase-Schramm, A., Bock, B., Linke, P., 2003. U/Th systematics and ages of authigenic carbonates from Hydrate Ridge, Cascadia Margin: recorders of fluid flow variations. Geochim. Cosmochim. Acta 67, 3845-3857.

Vigier, N., Bourdon, B., Turner, S., Allègre, C.J., 2001. Erosion timescales derived from U-decay series measurements in rivers. Earth Planet. Sci. Lett. 193, 549-563.

Zhong, S., Mucci, A., 1993. Calcite precipitation in seawater using a constant addition $713 \quad 57,1409-1417$. 


\section{Table captions}

\section{Table 1}

$717<$ DL means concentration lower than the instrumental detection limit.

\section{Table 2}

720 Depths indicated for samples correspond to centimetres below the surface of the crust.

721 Round brackets denote activity ratio. All calculations have used the half-lives 722 measured by Cheng et al. (2000).

\section{Table 3}

725 Depths indicated for samples correspond to centimetres below the top of the crust. 726 Initial $\delta^{234} \mathrm{U}$ represents the deviation in permil of $\left({ }^{234} \mathrm{U} /{ }^{238} \mathrm{U}\right)$ from its secular 727 equilibrium value of 1.000 , at the time T of carbonate precipitation, with initial $\delta^{234} \mathrm{U}=$ $728\left[\left\{\left({ }^{234} \mathrm{U} /{ }^{238} \mathrm{U}\right)_{\mathrm{T}} /\left({ }^{234} \mathrm{U} /{ }^{238} \mathrm{U}\right)_{\mathrm{equ}}\right\}-1\right] \times 10^{3}$. Measured values (see Table 2) are corrected 729 for detrital contamination and decay of excess ${ }^{234} \mathrm{U}$ since sample formation. One 730 sample $(0.0 \mathrm{~cm})$ is rejected as meaningful age based on the presence of significant 731 seawater ${ }^{230}$ Th (see text for details), and is shown in italics. Other calculated ages are 732 considered reliable. All calculations have used the half-lives measured by Cheng et al. 733 (2000).

\section{Figure captions}

\section{Figure 1}

738 Shaded bathymetric map of the Central Nile deep-sea fan (Loncke et al., 2006), and 739 location of the studied carbonate crust. Crust NL7-CC2 was collected from a 740 carbonate-paved area, at an active zone of fluid venting located at $\sim 1650 \mathrm{~m}$ water 741 depth.

\section{Figure 2}


744 Description of carbonate crust NL7-CC2. (A) Seafloor bottom photograph showing 745 sampling with the Nautile submersible. Upon recovery, numerous living 746 vestimentiferan tubeworms were observed anchored at the base of the crust. (B)

747 Cross-section. Crust NL7-CC2 is a highly porous carbonate-cemented mudstone 748 covered by a fine layer of Fe-oxyhydroxides. Numerous fragments of bivalve shells 749 are observed in the upper $\sim 1-\mathrm{cm}$ of the crust. Fibrous aragonite is present in open pore 750 spaces, either in cracks or inside the cavities of biogenic components. Crust NL7-CC2 751 is dominated by aragonite, but exhibits mineralogical variability, characterized by a 752 gradual enrichment in high-Mg carbonate phases from top to bottom (Gontharet et al., 753 2007). The areas of the crust sampled for U-Th analysis are shown as white-filled 754 squares (hand-drilled samples), green-filled rectangles (micromilled samples). The 755 micromilled sample at $0.0 \mathrm{~cm}$ (crossed red-filled rectangle) was rejected as meaningful 756 age based on the presence of significant seawater ${ }^{230} \mathrm{Th}$ (see text for details).

\section{$758 \quad$ Figure 3}

759 High-resolution profiles for A) $\mathrm{Sr} / \mathrm{Ca}$ ratios; B) $\mathrm{Mg} / \mathrm{Ca}$ ratios; C) detritus contents 760 (wt\%); D) $\delta^{13} \mathrm{C}(\% \circ \mathrm{PDB})$, Gontharet et al. (2007); and E) ${ }^{230} \mathrm{Th} / \mathrm{U}$ ages (kyr BP) across 761 NL7-CC2 crust. A), B), C) The small empty squares correspond to electron 762 microprobe data, and the larger infilled squares to XRF analyses of bulk carbonate 763 crust samples. Detrital contents were calculated by summing contents (wt \%) of XRF 764 data for $\mathrm{K}_{2} \mathrm{O}, \mathrm{Fe}_{2} \mathrm{O}_{3}, \mathrm{SiO}_{2}, \mathrm{TiO}_{2}$ and $\mathrm{Al}_{2} \mathrm{O}_{3}$ (see Table 1). Below the aragonite-rich 765 upper crust layer, the frequency of high $\mathrm{Mg} / \mathrm{Ca}$ values increases progressively with 766 depth, indicating enhanced contribution from high-Mg carbonate phases. Detrital 767 contents in crust NL7-CC2 can be as high as $\sim 12 \mathrm{wt} \%$, increasing progressively with 768 depth. D) The progressive downward depletion in carbonate ${ }^{13} \mathrm{C}$ in crust NL7-CC2 769 indicates an increasing contribution from AOM-derived versus seawater-derived 770 carbon in the lower part of the crust (Gontharet et al., 2007). E) The ${ }^{230} \mathrm{Th} / \mathrm{U}$ ages vary 771 from $\sim 4.9 \pm 1.2 \mathrm{ka}$ in the topmost part of the crust to $\sim 0.8 \pm 1.3 \mathrm{ka}$ at its base, 772 indicating that the crust has grown downward. Three growth periods can be 773 distinguished from top to bottom (dashed lines), with average growth rates of $\sim 0.4,5$ 774 and $0.8 \mathrm{~cm} / \mathrm{kyr}$, respectively (thick lines). Those growth variations are accompanied 775 by changes in carbonate mineralogy (see $\mathrm{Sr} / \mathrm{Ca}$ and $\mathrm{Mg} / \mathrm{Ca}$ profiles) and fluid 776 composition (see $\delta^{13} \mathrm{C}$ values). The vertical error bars shown in panels D) and E) 
777 correspond to sample thickness. The horizontal error bars are 2sd uncertainties on 778 isochron ages.

$780 \quad$ Figure 4

781 A) Rosholt isochron diagram for bulk and micromilled carbonate samples (crust NL7$782 \mathrm{CC} 2$ ). Isochron ages are calculated from the slope of the isochrons, using a sediment 783 end-member defined as the average of the two studied sediments. The values for the 784 sediment end-member are $\left({ }^{230} \mathrm{Th} /{ }^{232} \mathrm{Th}\right)=2.30 \pm 0.47(2 \mathrm{SD})$ and $\left({ }^{238} \mathrm{U} /{ }^{232} \mathrm{Th}\right)=0.87 \pm$ 7850.02 (2SD). The dashed line represents the equiline. Note the large error bars on $786\left({ }^{238} \mathrm{U} /{ }^{232} \mathrm{Th}\right)$ ratios for samples drilled at $0.4 \mathrm{~cm}, 0.9 \mathrm{~cm}$ and $2.8 \mathrm{~cm}$ depth below the 787 crust surface, which prevent calculation of reliable ages. B) Comparison of $788\left({ }^{230} \mathrm{Th} /{ }^{232} \mathrm{Th}\right)$ vs. $\left({ }^{238} \mathrm{U} /{ }^{232} \mathrm{Th}\right)$ ratios of cold seep carbonates from different settings, 789 including our carbonate crust samples from the Nile deep-sea fan, carbonate nodules 790 collected in hydrate-bearing sediments from methane seeps off Joetsu (Eastern Margin 791 of Japan Sea; Watanabe et al., 2008), and aragonite chemoherms recovered on the 792 seafloor at the Hydrate Ridge (Cascadia Margin; Teichert et al., 2003). Note that the $793\left({ }^{238} \mathrm{U} /{ }^{232} \mathrm{Th}\right)$ ratios decrease from the Hydrate Ridge chemoherm carbonates (from 794100 to 10000 ), the crust samples from the Nile margin (from 15 to 175 ; this study), 795 and the carbonate nodules from the Japan Sea (from $\sim 4$ to 16), which may reflect, at 796 least partly, an increasing contamination by detrital material during carbonate 797 precipitation.

\section{Figure 5}

800 Schematic diagram for the mode of formation of the studied carbonate crust, 801 integrating mineralogical and geochemical data, and calculated ${ }^{230} \mathrm{Th} / \mathrm{U}$ ages. A) 802 Stage 1 (from $\sim 5 \pm 1$ to $3 \pm 1 \mathrm{kyr}$ BP) - onset of fluid venting at the studied location 803 leading to development of chemosynthetic communities on the seafloor and aragonite 804 precipitation. Aragonite precipitates near the seafloor, cementing shell fragments of 805 chemosynthetic bivalves. At this stage, the formation of a cm-thick aragonite crust can 806 reduce the exchange of dissolved species between sediment and bottom water, leading 807 to reduced AOM rates and, possibly, to partial aragonite dissolution. B) Stage 2 (from $808 \sim 3 \pm 1$ to $2 \pm 1 \mathrm{kyr} \mathrm{BP}$ ) - rapid growth of the carbonate crust. The absence of 809 significant bioturbation and an efficient supply of seawater sulphate at the base of the 
810 crust via vestimentiferan tubeworms (bioirrigation), lead to high rates of AOM 811 (anaerobic oxidation of methane) turnover promoting fast carbonate precipitation 812 (mainly aragonite). C) Stage 3 (from $\sim 2 \pm 1 \mathrm{kyr}$ BP to present) - reduced rates of 813 carbonate formation. The bottom part of the crust becomes isolated from seawater, 814 leading to reduced supply of sulphate by bioirrigation. The sulphate depletion at the 815 base of the crust induces lower AOM rates and preferential precipitation of high-Mg 816 calcite over aragonite. 
Table 1. XRF major element composition of bulk carbonate and sediment samples

\begin{tabular}{|c|c|c|c|c|c|c|c|c|c|c|c|c|c|c|}
\hline San & $\begin{array}{c}\mathrm{SiO}_{2} \\
\%\end{array}$ & $\begin{array}{c}\mathrm{Al}_{2} \mathrm{O}_{3} \\
\%\end{array}$ & $\begin{array}{c}\mathrm{Fe}_{2} \mathrm{O}_{3} \\
\%\end{array}$ & $\begin{array}{c}\mathrm{MnO} \\
\%\end{array}$ & $\begin{array}{c}\mathrm{MgO} \\
\%\end{array}$ & $\begin{array}{c}\mathrm{CaO} \\
\%\end{array}$ & $\begin{array}{c}\mathrm{Na}_{2} \mathrm{O} \\
\%\end{array}$ & $\begin{array}{c}\mathrm{K}_{2} \mathrm{O} \\
\%\end{array}$ & $\begin{array}{c}\mathrm{TiO}_{2} \\
\%\end{array}$ & $\begin{array}{c}\mathrm{P}_{2} \mathrm{O}_{5} \\
\%\end{array}$ & $\begin{array}{c}\mathrm{SO}_{4} \\
\%\end{array}$ & $\begin{array}{c}\text { LOI } \\
\%\end{array}$ & $\begin{array}{c}\mathrm{Sr} \\
\mathrm{ppm}\end{array}$ & Total \\
\hline \multicolumn{15}{|c|}{ NL7-CC2 crust (N32 $31.61^{\prime}, \mathrm{E} 30^{\circ} 21.16^{\prime}, 1686 \mathrm{~m}$ water depth) } \\
\hline & 73 & 0.74 & 0.31 & 0.004 & 0.49 & 50.73 & 0.33 & 0.03 & 0.05 & 0.01 & 0.17 & 69 & 5708 & 98.84 \\
\hline & 3.13 & 1.21 & 0.44 & DL & 0.53 & & 0.44 & 0.06 & 0.08 & 0.04 & 0.24 & 30 & 82 & 98.82 \\
\hline & 84 & 1.55 & 0.65 & $<\mathrm{DL}$ & 1.07 & 48 & 0.44 & 0.08 & 0.09 & 0.03 & 0.61 & 39 & 34 & 99.12 \\
\hline & .27 & 1.73 & 0.73 & $<\mathrm{DL}$ & 1.39 & 4 & 0.40 & 0.09 & 0.10 & 0.03 & 0.65 & 57 & 43 & 98.86 \\
\hline 4-5. & 7.55 & 3.14 & 1.54 & $<\mathrm{DL}$ & 3.06 & 41.94 & 0.46 & 0.17 & 0.19 & 0.01 & 1.36 & 38.96 & 5497 & 98.92 \\
\hline \multicolumn{15}{|c|}{ NL7-BC1 sediment $\left(\mathrm{N} 32^{\circ} 30.50^{\prime}, \mathrm{E} 30^{\circ} 23.09^{\prime}, 1623 \mathrm{~m}\right.$ water depth) } \\
\hline & 20.56 & 7.00 & 3.11 & 0.10 & 3.43 & 31.95 & 0.71 & 0.26 & 0.41 & 0.10 & 0.90 & & 1248 & 99.51 \\
\hline \multicolumn{15}{|c|}{ NL14-PC1 sediment (N32³8.33', E2955.80', 2116 m water depth) } \\
\hline & 24.21 & 8.21 & 4.28 & 0.07 & 2.96 & 27.69 & 1.19 & 0.32 & 0.54 & 0.13 & 0.54 & 29.67 & 1132 & 99.81 \\
\hline
\end{tabular}


Table 2. Measured U-Th data for sediment and carbonate samples

\begin{tabular}{|c|c|c|c|c|c|c|c|c|c|}
\hline \multirow{2}{*}{$\begin{array}{c}\text { Sample } \\
\text { ediments }\end{array}$} & \multirow[t]{2}{*}{ Description } & \multirow[t]{2}{*}{$\begin{array}{l}\text { Weight } \\
\text { (mg) }\end{array}$} & \multicolumn{2}{|c|}{$\begin{array}{c}{ }^{238} \mathrm{U}(\mathrm{ppm}) \\
\pm 2 \sigma\end{array}$} & \multicolumn{2}{|c|}{$\begin{array}{c}{ }^{232} \mathrm{Th}(\mathrm{ppb}) \\
\quad \pm 2 \sigma\end{array}$} & \multirow[t]{2}{*}{$\begin{array}{l}\left({ }^{234} U /^{238} U\right) \\
\quad \pm 2 \sigma\end{array}$} & \multirow[t]{2}{*}{$\begin{array}{c}\left({ }^{230} \mathrm{Th} /{ }^{232} \mathrm{Th}\right) \\
\quad \pm 2 \sigma\end{array}$} & \multirow[t]{2}{*}{$\begin{array}{l}\left({ }^{238} \mathrm{U} /{ }^{232} \mathrm{Th}\right) \\
\quad \pm 2 \sigma\end{array}$} \\
\hline & & & & & & & & & \\
\hline NL14-PC1 & & 51.43 & $1.420 \pm$ & 0.002 & $4939.5 \pm$ & 18.5 & $1.025 \pm 0.002$ & $2.48 \pm 0.01$ & $0.878 \pm 0.003$ \\
\hline NL7-BC1 & & 50.82 & $1.261 \pm$ & 0.002 & $4214.1 \pm$ & 13.1 & $1.041 \pm 0.002$ & $2.17 \pm 0.01$ & $0.914 \pm 0.003$ \\
\hline & replicate & 327.7 & $1.239 \pm$ & 0.002 & $4634.0 \pm$ & 17.2 & $1.053 \pm 0.002$ & $2.12 \pm 0.02$ & $0.817 \pm 0.003$ \\
\hline \multicolumn{10}{|c|}{ NL7-CC2 carbonate crust } \\
\hline $0.0 \mathrm{~cm}$ & bulk & 166.6 & $4.85 \pm$ & 0.01 & $861.3 \pm$ & 2.2 & $1.143 \pm 0.002$ & $3.83 \pm 0.01$ & $17.20 \pm 0.05$ \\
\hline $0.1 \mathrm{~cm}$ & micromilled & 1.14 & $4.05 \pm$ & 0.07 & $228.5 \pm$ & 29.4 & $1.138 \pm 0.003$ & $5.47 \pm 0.17$ & $54.2 \pm 7.0$ \\
\hline $0.4 \mathrm{~cm}$ & micromilled & 1.06 & $3.29 \pm$ & 0.06 & $115.8 \pm$ & 44.9 & $1.128 \pm 0.009$ & $6.49 \pm 0.55$ & $86.9 \pm 33.7$ \\
\hline $0.9 \mathrm{~cm}$ & micromilled & 1.06 & $1.67 \pm$ & 0.03 & $29.1 \pm$ & 4.1 & $1.132 \pm 0.009$ & $11.54 \pm 0.41$ & $174.9 \pm 24.7$ \\
\hline $1.0 \mathrm{~cm}$ & bulk & 43.48 & $8.40 \pm$ & 0.01 & $885.7 \pm$ & 3.7 & $1.141 \pm 0.002$ & $3.10 \pm 0.01$ & $28.96 \pm 0.13$ \\
\hline $2.2 \mathrm{~cm}$ & micromilled & 0.95 & $10.44 \pm$ & 0.22 & $697.0 \pm$ & 4.0 & $1.142 \pm 0.003$ & $3.88 \pm 0.05$ & $45.73 \pm 1.00$ \\
\hline $2.5 \mathrm{~cm}$ & micromilled & 0.56 & $8.79 \pm$ & 0.31 & $689.1 \pm$ & 8.1 & $1.137 \pm 0.005$ & $3.53 \pm 0.05$ & $38.95 \pm 1.47$ \\
\hline \multirow[t]{2}{*}{$2.5 \mathrm{~cm}$} & bulk & 111.0 & $12.85 \pm$ & 0.02 & $1323.6 \pm$ & 4.6 & $1.144 \pm 0.002$ & $2.91 \pm 0.01$ & $29.65 \pm 0.11$ \\
\hline & replicate & 466.1 & $12.29 \pm$ & 0.02 & $1383.7 \pm$ & 4.3 & $1.144 \pm 0.002$ & $2.81 \pm 0.04$ & $27.12 \pm 0.09$ \\
\hline $2.8 \mathrm{~cm}$ & micromilled & 0.82 & $5.37 \pm$ & 0.13 & $202.0 \pm$ & 69.6 & $1.129 \pm 0.009$ & $5.25 \pm 0.25$ & $81.2 \pm 28.0$ \\
\hline $3.6 \mathrm{~cm}$ & micromilled & 1.50 & $8.31 \pm$ & 0.11 & $583.9 \pm$ & 8.4 & $1.140 \pm 0.003$ & $3.37 \pm 0.12$ & $43.46 \pm 0.85$ \\
\hline $4.3 \mathrm{~cm}$ & micromilled & 1.37 & $10.62 \pm$ & 0.16 & $956.8 \pm$ & 40.0 & $1.142 \pm 0.003$ & $3.14 \pm 0.08$ & $33.89 \pm 1.50$ \\
\hline $5.0 \mathrm{~cm}$ & bulk & 502.8 & $20.85 \pm$ & 0.03 & $2141.9 \pm$ & 4.8 & $1.147 \pm 0.002$ & $2.58 \pm 0.04$ & $31.14 \pm 0.10$ \\
\hline $5.5 \mathrm{~cm}$ & bulk & 103.0 & $20.82 \pm$ & 0.03 & $2044.6 \pm$ & 5.8 & $1.144 \pm 0.002$ & $2.57 \pm 0.01$ & $29.69 \pm 0.08$ \\
\hline
\end{tabular}


Table 3. Activity ratios used for age calculation and U-Th ages for carbonate samples

\begin{tabular}{|c|c|c|c|c|c|c|}
\hline Sample & $\begin{array}{c}\left({ }^{232} \mathrm{Th} /{ }^{238} \mathrm{U}\right) \\
\pm 2 \sigma\end{array}$ & $\begin{array}{c}\left({ }^{230} \mathrm{Th} /{ }^{238} \mathrm{U}\right) \\
\pm 2 \sigma\end{array}$ & \multicolumn{2}{|c|}{$\begin{array}{c}\left({ }^{234} U / /^{238} U\right) \\
\pm 2 \sigma\end{array}$} & $\begin{array}{c}\text { Corrected U-Th age (ka) } \\
\pm 2 \sigma\end{array}$ & $\begin{array}{c}\text { Initial } \delta^{234} \cup(\%) \\
\pm 2 \sigma \\
\end{array}$ \\
\hline \multicolumn{7}{|l|}{ Sediment end-member } \\
\hline & $1.149 \pm 0.029$ & $2.65 \pm 0.47$ & \multicolumn{2}{|c|}{$1.036 \pm 0.030$} & & \\
\hline \multicolumn{7}{|c|}{ NL7-CC2 carbonate crust } \\
\hline $0.0 \mathrm{~cm}$ & $0.0581 \pm 0.0002$ & $0.2224 \pm 0.0010$ & $1.143 \pm$ & 0.002 & $9.1 \pm 2.5$ & $153 \pm 2$ \\
\hline $0.1 \mathrm{~cm}$ & $0.0185 \pm 0.0024$ & $0.0917 \pm 0.0083$ & $1.138 \pm$ & 0.003 & $4.9 \pm 1.2$ & $142 \pm 2$ \\
\hline $0.4 \mathrm{~cm}$ & $0.0115 \pm 0.0045$ & $0.0624 \pm 0.0181$ & $1.128 \pm$ & 0.005 & $3.5 \pm 2.1$ & $130 \pm 9$ \\
\hline $0.9 \mathrm{~cm}$ & $0.0057 \pm 0.0017$ & $0.0423 \pm 0.0124$ & $1.132 \pm$ & 0.005 & $2.8 \pm 1.3$ & $134 \pm 9$ \\
\hline $1.0 \mathrm{~cm}$ & $0.0345 \pm 0.0001$ & $0.1053 \pm 0.0005$ & $1.141 \pm$ & 0.002 & $2.5 \pm 1.4$ & $145 \pm 2$ \\
\hline $2.2 \mathrm{~cm}$ & $0.0219 \pm 0.0001$ & $0.0805 \pm 0.0009$ & $1.142 \pm$ & 0.003 & $2.95 \pm 0.88$ & $145 \pm 3$ \\
\hline $2.5 \mathrm{~cm}$ & $0.0257 \pm 0.0003$ & $0.0817 \pm 0.0013$ & $1.137 \pm$ & 0.005 & $2.2 \pm 1.0$ & $140 \pm 5$ \\
\hline $2.5 \mathrm{~cm}$ & $0.0337 \pm 0.0001$ & $0.0976 \pm 0.0003$ & $1.144 \pm$ & 0.002 & $2.0 \pm 1.4$ & $148 \pm 2$ \\
\hline replicate & $0.0369 \pm 0.0001$ & $0.1034 \pm 0.0004$ & $1.144 \pm$ & 0.002 & $1.8 \pm 1.5$ & $148 \pm 2$ \\
\hline $2.8 \mathrm{~cm}$ & $0.0123 \pm 0.0042$ & $0.0548 \pm 0.0085$ & $1.129 \pm$ & 0.005 & $2.6 \pm 1.4$ & $131 \pm 9$ \\
\hline $3.6 \mathrm{~cm}$ & $0.0230 \pm 0.0004$ & $0.0741 \pm 0.0012$ & $1.140 \pm$ & 0.003 & $2.06 \pm 0.93$ & $142 \pm 3$ \\
\hline $4.3 \mathrm{~cm}$ & $0.0295 \pm 0.0013$ & $0.0896 \pm 0.0054$ & $1.142 \pm$ & 0.003 & $2.1 \pm 1.3$ & $144 \pm 3$ \\
\hline $5.0 \mathrm{~cm}$ & $0.0337 \pm 0.0001$ & $0.0862 \pm 0.0004$ & $1.144 \pm$ & 0.002 & $0.8 \pm 1.3$ & $150 \pm 2$ \\
\hline $5.5 \mathrm{~cm}$ & $0.0321 \pm 0.0001$ & $0.0827 \pm 0.0003$ & $1.147 \pm$ & 0.002 & $0.8 \pm 1.3$ & $148 \pm 2$ \\
\hline
\end{tabular}




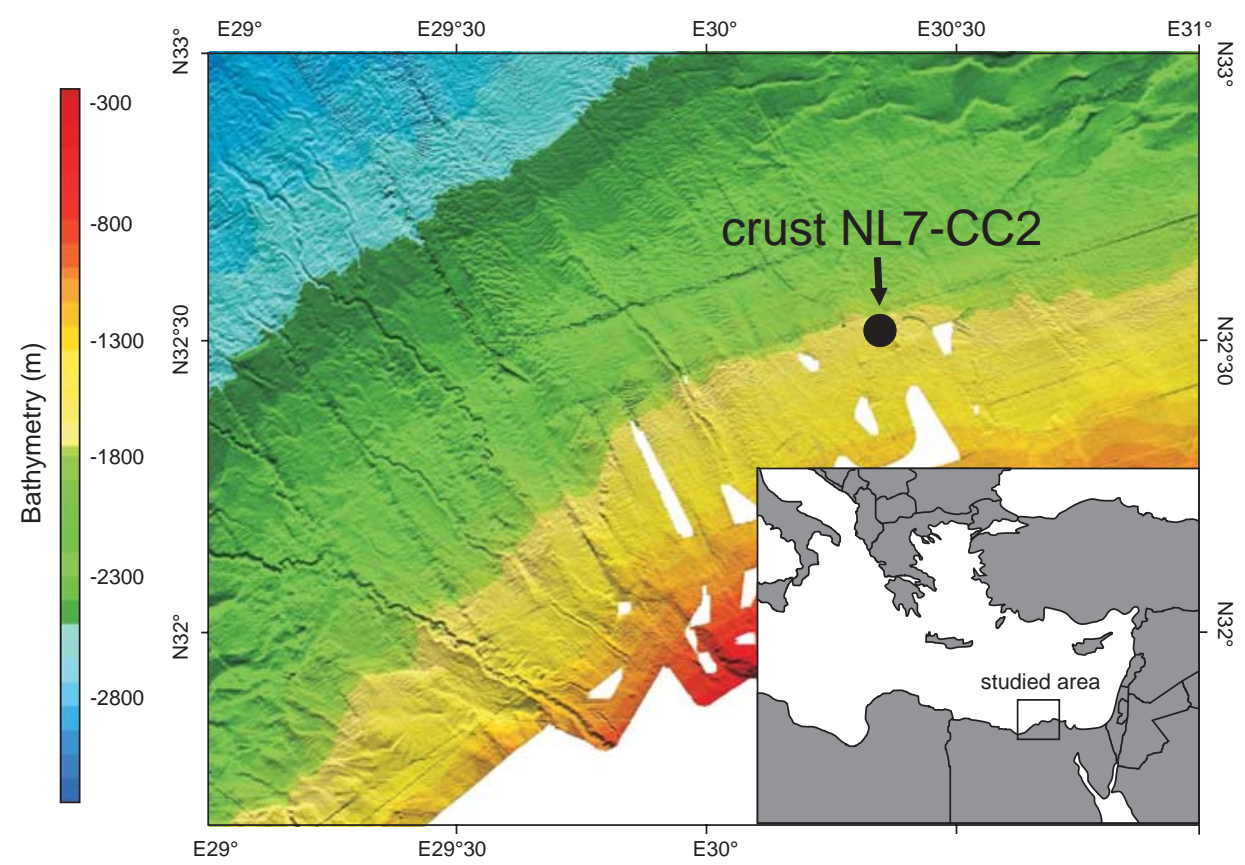

Fig1 (in colour) 


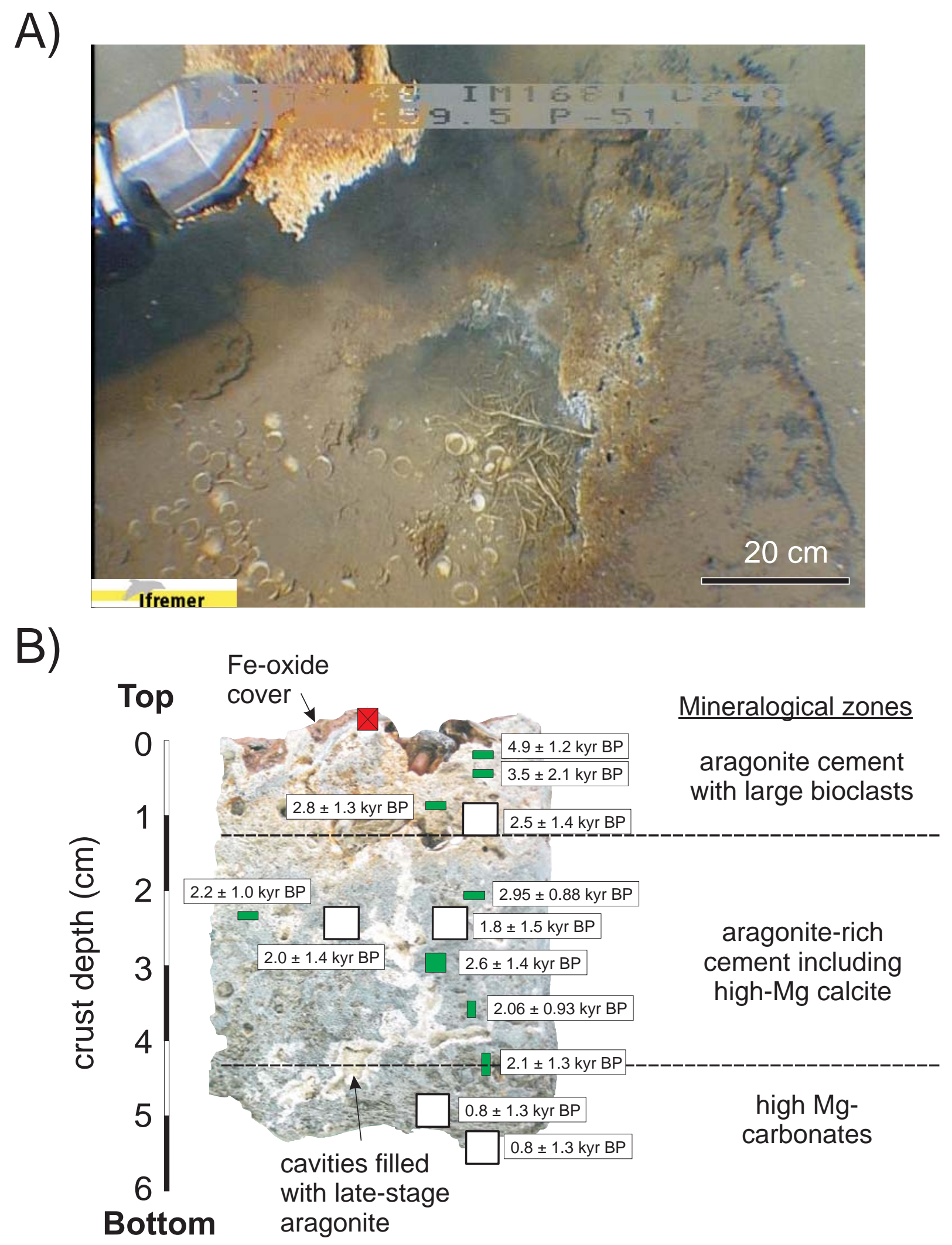

Fig. 2 (in colour in print) 


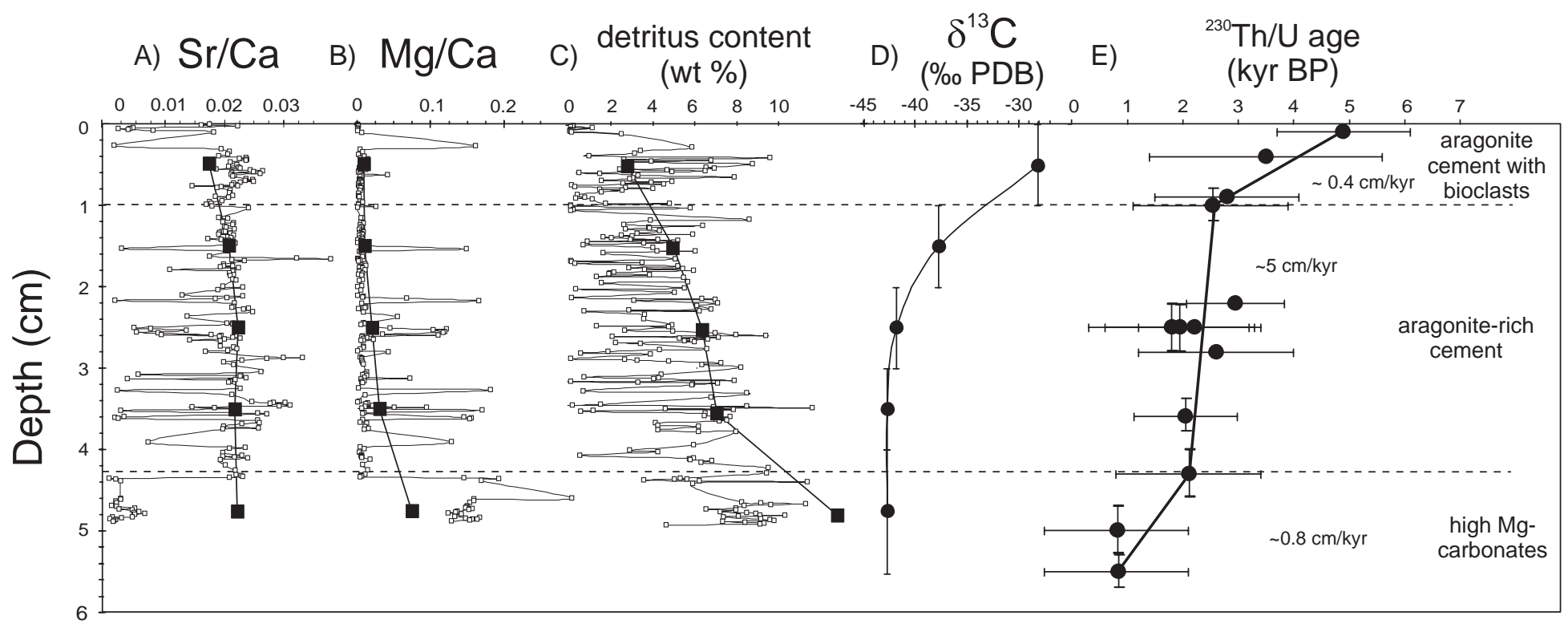

Fig. 3 
A)

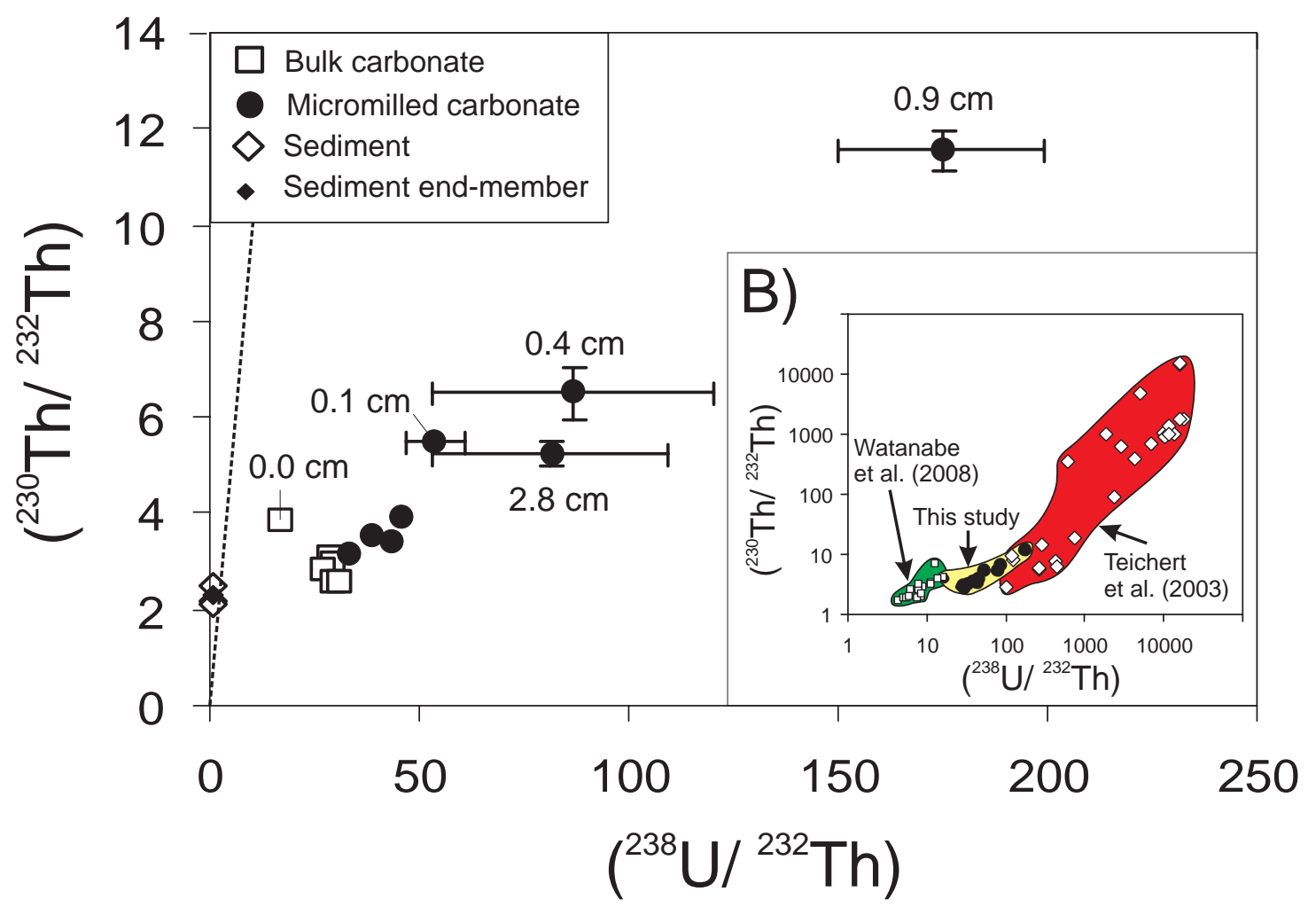

Fig. 4 


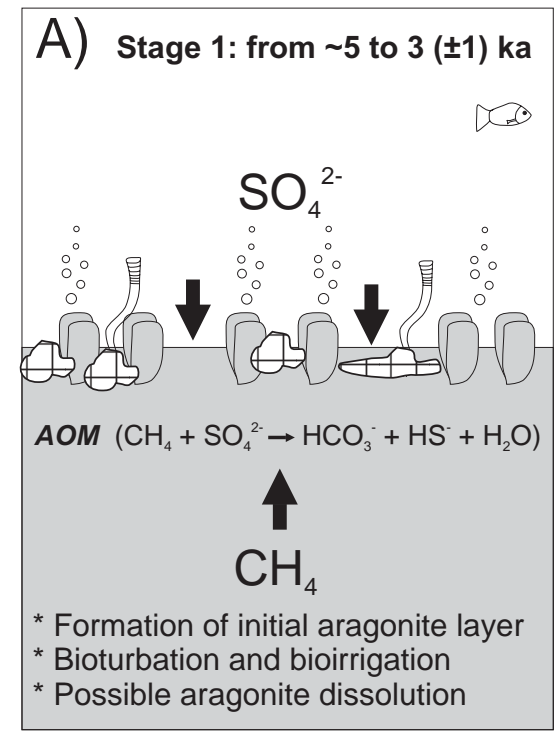

Carbonate/sediment facies Aragonite-cement with bioclasts

Aragonite-rich cement

High-Mg carbonates (high-calcite, dolomite)

Hemipelagic sediment

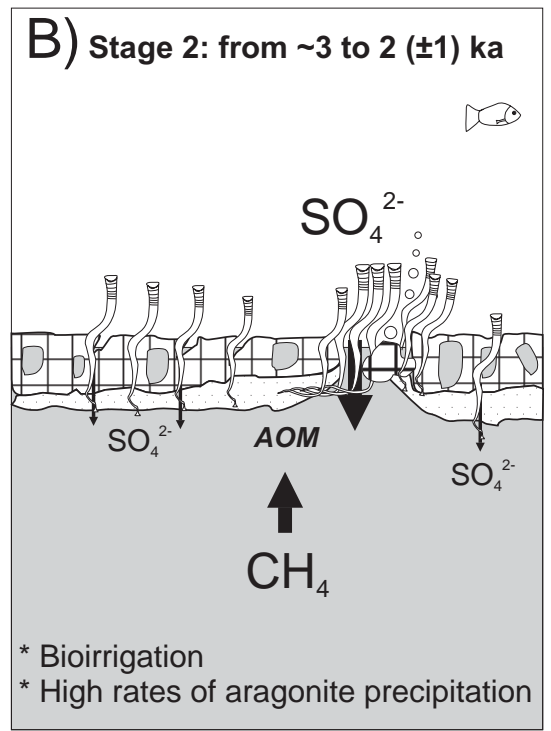

C) Stage 2: from 2 ( \pm 1$)$ ka to present

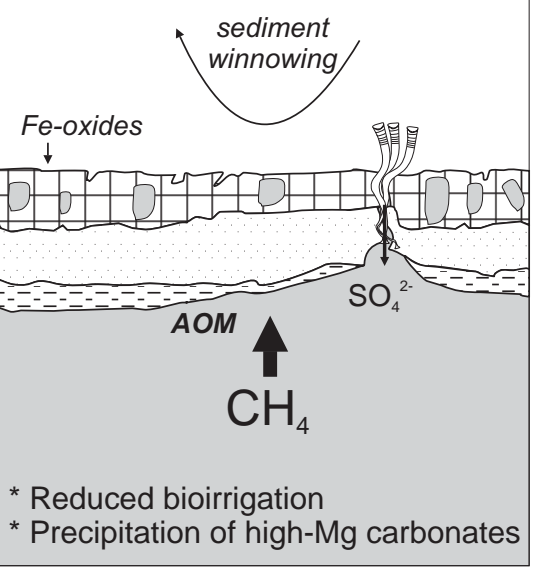

Chemiosynthetic communities

\section{Bivalves}

(clams, mussels)

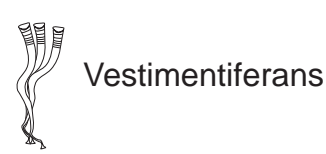

Solute transport Downward flux of
dissolved sulphate
(by diffusion, bioturbation,
and/or bioirrigation)

- Upward flux of

- methane-rich fluids (by diffusion and/or advection)

\section{Fig. 5}

